\title{
ESTABILIDADE CONSTITUCIONAL E ACORDOS CONSTITUCIONAIS: OS PROCESSOS CONSTITUINTES DE BRASIL (1987-1988) E ESPANHA (1977-1978)
}

\author{
Antonio Gomes Moreira Maués e Élida Lauris dos Santos
}

CONSTITUTIONAL STABILITY AND CONSTITUTIONAL AGREEMENTS: THE CONSTITUENT PROCESS OF BRAZII (1987-1988) AND SPAIN (1977-1978)

\begin{abstract}
RESUMO
O ARTIGO ANALISA OS ACORDOS QUE FORMARAM AS MAIORIAS nAs Assembléias Constituintes de Brasil (1987-1988) e ESPANHA (1977-1978), BUSCANDO IDENTIFICAR SUA CONTRIBUIC̄ÃO PARA A ESTABILIDADE CONSTITUCIONAL DOS DOIS PAÍSES. O ESTUDO FOI DESENVOLVIDO EM TRÊS NÍVEIS: ESTUDO DAS NORMAS REGIMENTAIS DAS ASSEMBLÉIAS CONSTITUINTES; TABULAÇÃO DAS VOTAÇÕES QUE APROVARAM DISPOSITIVOS CONSTITUCIONAIS; E ANÁLISE DOS DEBATES CONSTITUCIONAIS, NA QUAL FORAM IDENTIFICADOS TRÊS PROCESSOS DE FORMACุÃO DE MAIORIAS, CONCESSÕES MÚTUAS, NÃO-DECISÃO E MAIORIA ARITMÉTICA. O TRABALHO DEMONSTRA QUE O USO DE CONCESSÕES MÚTUAS E DA NÃO-DECISÃO NA CONSTITUINTE FAVORECE O PROCESSO DE CONSTRUÇÃO DO CONSENSO EM TORNO DA CONSTITUIÇÃO, CONTRIBUINDO PARA SUA ESTABILIDADE.

PALAVRAS-CHAVE

Poder Constituinte; Estabilidade Constitucional; Estudo

Comparativo; Brasil; EsPanha
\end{abstract}

\begin{abstract}
THE ARTICLE ANALYSES THE AGREEMENTS WHICH FORMED THE MAJORITIES IN THE CONSTITUENT ASSEMBLIES OF BRAZIL (1987-1988) AND SPAIN (1977-1978), TRYING TO IDENTIFY ITS CONTRIBUTION TO CONSTITUTIONAL STABILITY IN BOTH COUNTRIES. THIS ANALYSIS IS DEVELOPED THROUGH THREE STEPS: STUDY OF THE RULES THAT GOVERNED THE CONSTITUENT ASSEMBLIES; ORGANIZATION OF DATA ABOUT THE VOTINGS WHICH APPROVED CONSTITUTIONAL PROVISIONS; AND ANALYSIS OF THE CONSTITUTIONAL DEBATES, IN WHICH THREE PROCESS OF MAJORITY FORMATION HAVE BEEN IDENTIFIED, MUTUAL CONCESSIONS; NO-DECISION AND ARITHMETICAL MAJORITY. THE WORK SHOWS THAT THE USE OF MUTUAL CONCESSIONS AND NO-DECISION IN THE CONSTITUENT ASSEMBLY PROMOTES THE PROCESS OF CONSENSUS BUILDING REGARDING THE CONSTITUTION, CONTRIBUTING TO ITS STABILITY.

KEYWORDS

Constituent Power; Constitutional Stabilitty; Comparative STUDY; BRAZIL; SPAIN
\end{abstract}

\section{INTRODUÇÃO}

Os duzentos anos de história do constitucionalismo moderno presenciaram vários fracassos na busca de regular o poder do Estado por meio de Constituições escritas. A face mais aparente dessas tentativas frustradas mostra-se quando Constituições são suspensas ou revogadas após uma ruptura da ordem política. No entanto, mesmo Constituições há muito tempo em vigor podem também não alcançar o objetivo de submeter o poder do Estado ao direito. 
A vigência de uma Constituição escrita não significa que ela seja obedecida pelos poderes públicos, tal como ocorre em regimes autoritários que promulgam Constituições que não garantem a separação de poderes e os direitos fundamentais. Por outro lado, a eficácia de uma Constituição também pode ser afetada pela instabilidade de suas normas, que ocorre particularmente em três situações: na proposição de reformas constitucionais; na aprovação de reformas constitucionais; e na provocação do controle de constitucionalidade.

Mesmo que não sejam aprovadas, propostas de reforma expressam o dissenso de grupos políticos com a Constituição, o qual aumenta de importância quando esses grupos conseguem mobilizar a opinião pública em torno de sua crítica à regulação constitucional. A aprovação de reformas, por sua vez, pode garantir a estabilidade da Constituição no longo prazo, ao adaptá-la às mudanças sociais. No entanto, como lembra Konrad Hesse, ${ }^{1}$ reformas constitucionais freqüentes tendem a debilitar a força normativa da Constituição, por valorizarem mais as necessidades políticas, supostas ou reais, do que a regulação constitucional vigente. Isso diminui a confiança na inviolabilidade da Constituição e dificulta o seu reconhecimento como o conjunto de normas fundamentais da sociedade.

No caso da provocação do controle de constitucionalidade, os problemas para a estabilidade da Constituição decorrem da possibilidade de que ela tenha sido violada pela maioria política, o que pode gerar, na sua forma extrema, costumes contra constitutionem. ${ }^{2}$ Além disso, a utilização do controle de constitucionalidade, especialmente na forma concentrada, também pode significar uma tentativa de a minoria política impor à maioria limites não previstos pela Constituição, o que representa uma forma de violação do princípio democrático.

Apesar de suas diferenças, é possível que, em ambas as situações, subsistam incertezas sobre a regulação constitucional, mesmo após uma decisão do Tribunal Constitucional. Isso ocorre quando a dificuldade do caso leva a uma decisão por maioria, cujos fundamentos não são convergentes, o que deixa margem a dúvidas sobre a constitucionalidade de normas semelhantes. Por outro lado, mesmo que não existam divergências importantes no Tribunal Constitucional, a inconformidade da maioria política com a decisão pode levar à abertura de um processo de reforma constitucional.

Em todos esses casos, podemos notar que a instabilidade constitucional é provocada pelo fato da maioria ou da minoria políticas, em determinados momentos, recusarem a Constituição como marco de regulação de seus conflitos. No campo das reformas constitucionais, grupos que foram minoritários na Assembléia Constituinte mantêm vivo seu desacordo com a Constituição ou, ao se tornarem maioria, decidem adaptá-la aos seus objetivos políticos. No caso do controle de constitucionalidade, revela-se muitas vezes a tentativa da maioria de ultrapassar os limites constitucionais ou a tentativa da minoria de estender esses limites. 
Quando tais ações são constantes, a Constituição se torna um objeto permanente de conflitos e não a expressão dos acordos que fundamentam a convivência social. Assim, ainda que as Constituições escritas não sejam imutáveis, nem seja provável que os atores políticos jamais tentem forçar os limites constitucionais, o nível de instabilidade pode crescer a ponto de retirar da Constituição sua capacidade de regular a política.

Portanto, é fundamental para a estabilidade constitucional a existência de um acordo que vincule os atores políticos à Constituição, juntamente com os grupos e classes sociais que eles representam. Em outras palavras, que haja um consenso em torno da Constituição que faça com que esses atores - estejam eles em situação de maioria ou em situação de minoria - pautem suas ações pela obediência às normas constitucionais, mesmo quando elas contrariam seus interesses momentâneos.

A importância do consenso para a estabilidade constitucional pode ser compreendida, em grande parte, pelos conflitos que caracterizam a sociedade pluralista moderna marcada pela variedade de classes e grupos sociais e pela convivência de diferentes crenças e valores. ${ }^{3}$ Nesse contexto, a organização de um regime democrático tende a acentuar a disputa pelo poder público, pois a ampliação da participação e da competição políticas possibilita que um número maior de grupos exerça parcelas desse poder ou exija que seus interesses sejam levados em conta pelo Estado. Assim, ao mesmo tempo em que a democracia é necessária para instituir formas de resolução pacífica dos conflitos sociais, ela aumenta a possibilidade das decisões do governo contrariarem determinados interesses.

Quando essa insegurança atinge grupos que contam com recursos de poder na sociedade, é provável que os atores políticos que os representam somente reconheçam o direito dos oponentes de exercer o governo caso obtenham garantia de que seus interesses fundamentais serão resguardados da competição política. Portanto, a consolidação de uma democracia pluralista exige a constituição do governo por meio de eleições livres e imparciais e, ao mesmo tempo, que uma derrota eleitoral não implique a eliminação da vida política daqueles grupos que passam à oposição. ${ }^{4}$ Prover essa segurança será um dos principais encargos de uma Constituição que promova a transição de um regime autoritário para um regime democrático.

Esse "pedágio" que os atores políticos cobram para participar do jogo democrático acarreta uma limitação do poder das maiorias futuras, já que as normas constitucionais tornarão difícil ou mesmo juridicamente impossível alterar a proteção de determinados interesses. Caso esses limites não contem com o consenso dos principais atores - seja porque os consideram insuficientes, seja porque os consideram exagerados - é possível que eles aproveitem a condição de maioria para promover sua alteração, abrindo um período de instabilidade constitucional, por meio de reformas ou de atos inconstitucionais, ou mesmo propugnando por uma nova Constituição. 
Vale ressaltar que esse período de instabilidade prejudica não apenas a força normativa da Constituição, mas também impede uma maior institucionalização da democracia. Sem encontrar um ponto de equilíbrio consensual entre o que está e o que não está em disputa, a Constituição pode sofrer a acusação de ser débil, por não estabelecer os limites necessários ao poder da maioria, e também a acusação de ser inapropriada, por limitar excessivamente o poder da maioria. Assim, tanto Constituições procedimentais quanto Constituições dirigentes ${ }^{5}$ podem dificultar a obtenção do consenso em seu entorno, abrindo espaço para o questionamento freqüente das normas que regem o processo democrático. Sem embargo, enquanto no primeiro caso a regra de maioria é preservada, no segundo há uma tendência ao surgimento de crises de governabilidade, já que Constituições regulatórias possibilitam que a minoria política utilize a rigidez constitucional para impedir a implementação das propostas da maioria ou para obter vantagens em troca de sua aprovação. ${ }^{6}$

A busca desse consenso em torno dos limites impostos pela Constituição inicia-se no processo constituinte. ${ }^{7}$ Quando dele resulta um conjunto de decisões que preservam os interesses fundamentais dos principais atores políticos, será menor a probabilidade de que a Constituição seja alterada em decorrência de mudanças na maioria governante. Por essa razão, torna-se importante analisar os acordos que levaram à aprovação da Constituição, identificando como foram compostos os diferentes interesses presentes na Assembléia Constituinte.

Neste artigo, serão objeto de análise os processos constituintes de Brasil (1987-1988) e Espanha (1977-1978). A escolha desses dois casos justifica-se por uma série de razões. Em primeiro lugar, Brasil e Espanha promoveram a transição do regime autoritário a partir de um processo de negociação entre governo e oposição, que teve como um de seus principais traços a convocação de uma Assembléia Constituinte com base nas normas de reforma constitucional do regime autoritário. Esse caráter pactuado da transição implicava que o novo regime democrático deveria se basear em acordos entre os principais grupos políticos, cujo cenário seria a Constituinte.

Além disso, durante o longo período autoritário, os dois países passaram por um processo de modernização, que fez com que o processo constituinte não significasse apenas uma retomada do regime constitucional anterior, mas uma nova engenharia constitucional que abrigasse as classes e grupos sociais que haviam afluído no decorrer do período autoritário. Isso significou um processo constituinte cuja pauta era bastante ampla, tendo em vista a diversidade de interesses representados em seu interior.

A necessidade de firmar acordos decorria, ainda, do fato de não haver na Constituinte nenhum partido com maioria suficiente para elaborar a Constituição. $\mathrm{Na}$ Espanha, apesar da maioria relativa da União do Centro Democrático (UCD), que detinha 165 cadeiras $(47,14 \%$ ) do Congresso dos Deputados, era preciso contar com o apoio de outros grupos para alcançar a maioria, sendo particularmente importante 
a participação do Partido Socialista Operário Espanhol (PSOE), que, juntamente com o Partido dos Socialistas da Catalunha (PSC), ocupava 118 cadeiras (33,71\%) do Congresso dos Deputados. ${ }^{8}$ No caso brasileiro, apesar do Partido do Movimento Democrático Brasileiro (PMDB) deter a maioria absoluta na Constituinte (52\%), não havia homogeneidade para que sua bancada votasse de modo unificado as matérias. Assim, a Constituição teria que ser aprovada por parte do PMDB em conjunto com alguns dos demais partidos, resultando em acordos que oscilavam ora à direita, ora à esquerda. ${ }^{9}$ Essa situação contribuía para reforçar as demandas dos grupos que podiam ameaçar a aprovação da Constituição caso não fossem atendidos. ${ }^{10}$

Por fim, o resultado de ambos os processos constituintes, em relação à estabilidade constitucional, é oposto. A Constituição Espanhola foi reformada uma única vez, em 1992, para possibilitar a extensão, a residentes estrangeiros, do direito de sufrágio ativo e passivo nas eleições municipais, atendendo ao Tratado de Maastricht. A Constituição Brasileira recebeu 62 emendas até dezembro de 2007, muitas delas de conteúdo extenso e que modificaram pontos importantes do texto constitucional. Esse contraste faz com que a comparação entre os dois casos ajude a identificar a importância do processo constituinte para a estabilidade constitucional.

A análise dos acordos nessas duas Assembléias Constituintes foi desenvolvida em três níveis, sempre com base no exame de seus respectivos anais. ${ }^{11}$ No primeiro, realizamos o estudo das normas regimentais que presidiram seu funcionamento, buscando identificar os marcos em que os acordos poderiam ser estabelecidos e os procedimentos que favoreciam sua obtenção. No segundo, tabulamos as votações que aprovaram dispositivos constitucionais no Plenário do Congresso dos Deputados da Constituinte espanhola e no Plenário (primeiro turno) da Constituinte brasileira e calculamos seu desvio padrão, ${ }^{12}$ o que nos permitiu identificar as matérias mais polêmicas, bem como distinguir as votações consensuais das votações não consensuais.

Os dois primeiros estudos serviram de base para a análise dos debates constitucionais, na qual buscamos verificar o modo pelo qual as maiorias foram formadas, examinando sua relação com a estabilidade constitucional. Nesse estudo, utilizamos três categorias, concessões mútuas, não-decisão e maioria aritmética, que correspondem a três processos distintos de formação de maiorias na Constituinte.

O primeiro [processo] implica uma decisão em que há concessões mútuas entre os grupos políticos, concessões essas que significam tanto regular uma matéria de modo a atender a interesses divergentes, quanto aceitar a posição de um grupo em determinado tema para que ele ceda em outro. Esse modo de formação da maioria pode, muitas vezes, recorrer a fórmulas de compromisso, ${ }^{13}$ incorporando ao texto constitucional orientações normativas distintas sobre a matéria objeto de acordo.

No segundo processo, a maioria se forma para não decidir, adiando a resolução do conflito para a legislação infraconstitucional. Assim, sendo impossível um acordo, 
opta-se por atribuir à maioria política a decisão sobre a matéria, fazendo com que as normas constitucionais apenas atribuam competência ao legislador ordinário.

Por fim, a maioria forma-se tão-somente pelo critério aritmético, sem ampliar o apoio da decisão a um conjunto maior de grupos políticos. Assim, enquanto os dois primeiros processos tendem a gerar uma votação consensual, o terceiro processo tende a gerar uma votação não consensual.

Antes de ingressar na exposição, deve-se ressaltar que, mesmo acordos que incorporam amplas parcelas da Constituinte não significam unanimidade. A formação de maiorias em processos constituintes marcados pelo pluralismo sempre levará à formação de minorias. Assim, como é pouco provável que todos os interesses presentes sejam igualmente atendidos, a estabilidade constitucional também dependerá do acerto da Constituinte em selecionar os interesses daqueles grupos cuja adesão à Constituição é necessária para não colocá-la em risco.

\section{Análise dos Regimentos}

Os primeiros acordos da Constituinte são firmados em torno de seu regimento. Ao contrário das legislaturas ordinárias, que começam a trabalhar com base em regras pré-estabelecidas, as Constituintes têm como primeiro encargo a definição das normas de seu funcionamento, mesmo que algumas delas já estejam dispostas no momento de sua convocação. ${ }^{14}$ Além disso, as normas regimentais podem favorecer ou não a obtenção de acordos na Constituinte, tendo em vista, particularmente, o modo como determinam a elaboração do projeto de Constituição, a apresentação de emendas, os debates e a participação dos parlamentares na sua feitura.

A Constituição Espanhola foi redigida a partir do anteprojeto elaborado por uma comissão (Ponencia), formada por sete representantes dos Grupos Parlamentares. ${ }^{15}$ Esse anteprojeto foi apreciado em seguida pela Comissão Constitucional do Congresso dos Deputados e por seu Plenário, sendo posteriormente enviado para votação na Comissão Constitucional e no Plenário do Senado, cabendo a uma Comissão Mista das duas Casas a redação do texto final. ${ }^{16}$

Em todas as etapas, o regimento previa a possibilidade de modificação do projeto pelos integrantes do Parlamento por meio de emendas (na Ponencia, os participantes propunham votos particulares, em vez de emendas) que poderiam advir da iniciativa do Grupo Parlamentar ou, individualmente, de um Parlamentar, caso no qual a emenda deveria ser subscrita pelo porta-voz do Grupo para conhecimento da mesma. O processo espanhol dispunha também das emendas in voce, que representavam um entendimento entre os Grupos Parlamentares e eram propostas oralmente no momento dos debates (ver infra).

$\mathrm{Na}$ Constituinte brasileira, após uma demorada discussão de seu regimento (ver infra), houve a seguinte organização: 24 Subcomissões Temáticas, 8 Comissões 
Temáticas, ${ }^{17} 1$ Comissão de Sistematização, Votação de primeiro turno em Plenário, Votação de segundo turno em Plenário, e 1 Comissão de Redação. A elaboração do projeto de Constituição iniciou-se nas Subcomissões, que encaminharam seus anteprojetos às respectivas Comissões, cujos substitutivos foram enviados à Comissão de Sistematização.

A Comissão de Sistematização, formada inicialmente por 49 membros titulares, além dos Presidentes e Relatores das demais Comissões e Subcomissões, foi encarregada da compatibilização das matérias oriundas das Comissões. O texto saído da Comissão de Sistematização compôs o primeiro projeto de Constituição, denominado "Projeto A", 18 ao qual seguiu-se o "Projeto B", resultante da votação em primeiro turno, o "Projeto C”, saído da votação de segundo turno, e o "Projeto D”, que encerrou a elaboração constitucional após o trabalho da Comissão de Redação. ${ }^{19}$

Inicialmente, segundo a Resolução n. 2, a modificação do Projeto de Constituição oriundo da Comissão de Sistematização seria realizada mediante a propositura de emendas, desde que não substituíssem integralmente o projeto ou se referissem a mais de um dispositivo, sendo que no último caso estavam ressalvadas as hipóteses de modificações correlatas. Segundo a mesma Resolução, a autoria das emendas caberia aos Constituintes (emendas individuais) e aos eleitores (emendas populares). As emendas populares deveriam ser subscritas por 30 mil ou mais eleitores brasileiros, em listas organizadas por, no mínimo, três entidades associativas legalmente constituídas.

Entretanto, o Regimento da Assembléia Constituinte brasileira sofreu alterações substanciais com a aprovação da Resolução n. 3, de forma que os debates passaram a se organizar em torno de emendas coletivas, emendas de fusão (estas serão explicadas no item posterior) e destaques. A alteração do Regimento marca a formação definitiva do Centrão, agrupamento de tendência liberal-conservadora integrado, sobretudo, por PFL, PDS e PTB, e que teve importante atuação durante a Constituinte brasileira.

As emendas coletivas eram propostas pela maioria absoluta dos membros da Assembléia, podendo substituir integralmente títulos, capítulos, seções e subseções do Projeto de Constituição e tendo preferência na ordem de votação. Assim, tornouse possível que, no momento da votação em Plenário do texto proposto na Comissão de Sistematização, fosse aprovado um texto substitutivo apresentado através de uma emenda coletiva, que passava a servir de base para as votações.

Os destaques poderiam ser de três tipos: para supressão, para aprovação e para votação em separado. Aqueles que estivessem descontentes com algum dispositivo do texto substitutivo aprovado, poderiam requerer o destaque para sua supressão ou um destaque para aprovação do texto original da Sistematização. ${ }^{20}$

Além disso, mediante requerimento subscrito por 187 Constituintes, o Plenário apreciaria o destaque para votação em separado (DVS). Com essa modalidade de destaque, apartava-se determinado texto (dispositivo ou capítulo) do substitutivo para votação do Plenário, exigindo-se maioria absoluta - 280 votos - para sua aprovação. 
Assim, o DVS serviu como importante arma das minorias, pois a aprovação da emenda coletiva não impedia que as partes mais polêmicas do texto fossem destacadas para votação em separado. Tendo em vista o caráter polêmico dessas matérias, o DVS impunha que fosse feito um acordo para alcançar os 280 votos. $^{21}$

Esses elementos acentuam as diferenças entre os processos constituintes estudados, sendo visível que a Constituinte brasileira nasce com uma base ampla, possibilitada pela participação da sociedade nas audiências das subcomissões e comissões e na apresentação de emendas populares, mas se estreita durante o processo, a partir do momento em que as mudanças produzidas no Projeto de Constituição deslocaram as decisões para as negociações entre os grupos políticos. Por sua vez, o processo espanhol limitou a elaboração da Constituição, desde seu início, aos representantes partidários, mas, ao final, submeteu o projeto a referendo popular.

A efetividade das formas adotadas em cada processo deve ser observada de acordo com seus resultados práticos. Enquanto a Constituição espanhola, em um universo de 17.873.301 votos emitidos, contou com 15.706.078 votos "sim", das emendas populares brasileiras, somente uma chegou a ser aprovada em primeiro turno, tendo sido fundida com a propositura de outros partidos.

Em um processo constituinte como o brasileiro, em que a reforma do Regimento ampliou as possibilidades de alteração do projeto inicial, é compreensível que, nas votações em primeiro turno, 78,92\% da matéria aprovada tenham sido oriundos de emendas, enquanto $14,04 \%$ representaram a manutenção do texto aprovado na Sistematização. Já no caso espanhol, 94,84\% das votações no Plenário do Congresso dos Deputados mantiveram o texto aprovado na Comissão Constitucional, e apenas 5,16\% das votações configuraram a aprovação de emendas ao projeto de Constituição.

Para concluir essa discussão, cabe identificar, nos regimentos das Constituintes, os mecanismos que favoreciam a obtenção de acordos. Nas matérias de maior divergência, a composição de interesses deu-se pelas emendas in voce, na Espanha, e pelas fusões, no Brasil.

As emendas in voce eram reguladas da seguinte forma:

Art. 119 - En caso de que se formulasen enmiendas "in voce", cuyo texto deberá ser depositado en la Mesa de la Comisión, que sólo las admitirá a trámite si trataran de alcanzar un acuerdo entre los distintos criterios expuestos, el debate se realizará igualmente, mediante un turno a favor y uno en contra, con una duración máxima de 15 minutos cada uno.

Da leitura do dispositivo, surgem as seguintes conclusões: (a) as emendas originavam-se a partir de um acordo celebrado entre as lideranças; (b) eram apresentadas oralmente; e (c) continham uma proposta de acordo entre as emendas anteriores, daí a necessidade de um procedimento especial para sua tramitação. A análise das votações 
demonstra que as fórmulas que abriram espaço para as composições tenderam a alcançar maior sucesso, de tal modo que das dez emendas ao Projeto de Constituição espanhola aprovadas no Congresso dos Deputados, sete eram emendas in voce.

Na Constituinte brasileira, a fusão de emendas adveio com a Resolução n. 3, desde que a proposta de fusão (a) não apresentasse inovações em relação às demais emendas que a compunham; e (b) fosse assinada pelos primeiros subscritores das propostas originais.

Pela dinâmica das votações, sempre houve um inter-relacionamento entre emendas coletivas ${ }^{22}$ e fusões. Em um primeiro momento, as fusões eram utilizadas com o objetivo de aparar as arestas do substitutivo apresentado, ou seja, na votação das emendas coletivas construía-se um acordo em que os Constituintes se comprometiam a propor fusões para aperfeiçoar o texto do substitutivo. Contudo, esse acordo em torno do aperfeiçoamento do texto por meio das fusões não garantia a aceitação geral do substitutivo pela Assembléia, pois ainda podiam existir pontos considerados inconciliáveis, os quais eram levados para a decisão em Plenário, podendo resultar em uma nova negociação (mais fusões) ou na disputa voto a voto.

Apesar disso, as fusões foram um instrumento fartamente utilizado, inclusive trazendo inovações em seu texto. Em um segundo momento, precisamente após a derrota da emenda apresentada pela Centrão ao Capítulo II, do Título da Ordem Econômica, o substitutivo era aprovado quase como uma formalidade para fornecer à votação um texto base, sendo as fusões utilizadas como um segundo substitutivo, que alterava o primeiro.

Das 191 emendas aprovadas em primeiro turno, 140 (73,30\%) eram oriundas de fusões, enquanto 48 (25,13\%) eram emendas individuais. Não restam dúvidas de que as proposições que estimularam os membros da Assembléia ao acordo desfrutaram de um alto índice de aprovação. Na Constituinte brasileira, das 323 emendas rejeitadas, 70 (21,67\%) eram fusões e 247 (76,47\%), emendas individuais.

As conseqüências das diferenças regimentais também se revelam na análise quantitativa das votações. Considerando como votação consensual aquela que se inclui dentro do desvio padrão calculado a partir da base de votos "não" no Plenário do Congresso dos Deputados da Espanha (votações com até 19 votos contrários), e no primeiro turno da Constituinte brasileira (votações com até 85 votos contrários), no caso espanhol, somente $2 \%$ das votações foram não consensuais; no caso brasileiro, $15 \%$ das votações se enquadram nessa categoria. ${ }^{23}$

Tendo identificado a importância dos acordos na feitura das Constituições, devemos agora buscar esclarecer a natureza dos acordos estabelecidos, isto é, se incluíam a minoria nas decisões, se geraram votações consensuais ou se representaram, tão-somente, a imposição de uma maioria. Essas questões serão objeto das seções seguintes. 


\section{Os acordos na Constituinte ESPANHOla 24}

Aos olhos do observador estrangeiro, a Constituinte espanhola possui um caráter singular pela importância que o discurso do consenso adquiriu durante o processo. Todos os principais partidos políticos apresentavam-se à opinião pública propugnando que a Constituição fosse aceita por todos e defendendo suas posições em nome do consenso.

Essa característica manifesta particularidades da história espanhola. Desde o século XIX, a Espanha foi marcada pela instabilidade constitucional, vendo suas várias Constituições serem substituídas por outra de signo oposto. ${ }^{25}$ Além disso, a lembrança da guerra civil (1936-1939) mostrava a todos os grupos políticos a necessidade da convivência entre os adversários, a fim de superar a fratura do país.

Isso não significa que a transição para a democracia tenha ocorrido sem dificuldades. Após a morte do general Franco, em 1975, a perda de legitimidade do regime que ele comandava tornara-se patente, e impunha mudanças políticas. Contudo, a oposição - sem força suficiente para promover uma ruptura da ordem vigente levou a uma transição negociada que teve como base jurídica o ordenamento do regime autoritário. Assim, utilizando os procedimentos previstos nas leis fundamentais do franquismo e, após referendo popular, foi promulgada a Ley de Reforma Política (Lei 1/77), convocando eleições diretas para o Congresso dos Deputados e o Senado. ${ }^{26} \mathrm{O}$ art. $3^{\circ}$ dessa lei estabelecia um procedimento de "reforma constitucional", que poderia ser iniciado pelo Governo ou pelo Congresso dos Deputados, requerendo aprovação por maioria absoluta dos membros do Congresso e do Senado e sendo submetida igualmente a referendo. Paralelamente, o Governo tomava uma série de medidas que liberalizavam o regime, tal como o abrandamento da Lei de Ordem Pública, a ampliação do direito de associação política e de associação sindical, e a concessão de anistia. O momento mais marcante desse processo foi a legalização do Partido Comunista da Espanha.

Dessas eleições democráticas, saíram vitoriosos, em primeiro lugar, a União do Centro Democrático (UCD), de centro-direita, que, no entanto, não possuía maioria para fazer sozinha a Constituição. Em segundo lugar, o Partido Socialista Operário Espanhol (PSOE) e seus associados, de centro-esquerda, que firmara-se como a principal força de oposição.

Em que pesem as negociações entre governo e oposição incluírem a adoção de uma nova Constituição e a Lei de Reforma Política estabelecer um procedimento para sua elaboração, não era pacífica a necessidade dessa mudança, e nem mesmo os próprios representantes eleitos em 1977 estavam certos de haver recebido esse mandato do povo. ${ }^{27}$ Inicialmente, o Governo tentou elaborar um anteprojeto a partir de uma comissão de especialistas, o que não foi aceito pela oposição, que defendia que a iniciativa partisse do Parlamento. O primeiro passo foi a criação da Comissão Constitucional, em agosto de 1977, e a escolha da Ponencia (ver supra). Assim, o reconhecimento dos poderes constituintes do Parlamento eleito em junho de 1977 decorreu 
do próprio resultado eleitoral, no qual, apesar dos setores reformistas do regime terem obtido maioria relativa, o êxito do PSOE-PSC eliminava a possibilidade de a UCD controlar integralmente o processo de transição, sendo necessário negociar com a oposição para obter aprovação popular.

Como é amplamente sabido, o principal eixo de acordo na Constituinte espanhola deu-se entre UCD e PSOE-PSC. ${ }^{28}$ A força dessa aliança pode ser demonstrada pelas votações no Plenário do Congresso dos Deputados, no qual somente em oito ocasiões os dois partidos não votaram conjuntamente. ${ }^{29}$ Além dessa ampla maioria constituinte, a estabilidade constitucional espanhola também foi beneficiada do fato de o PSOE e seus aliados terem governado a Espanha de 1982 a 1996.

\section{I CONCESSÕES MÚtUAS}

Na maior parte dos casos, as votações da Constituinte espanhola seguem o padrão das concessões mútuas: os dois partidos majoritários logram um acordo sobre o texto constitucional, ao qual se somam, em quase todas as ocasiões, o Partido Comunista $(5,71 \%)$ e a Minoria Catalã $(3,71 \%)$. O principal grupo que ficou de fora desses acordos foi a Aliança Popular (AP), que detinha 4,57\% do Congresso dos Deputados, oriunda dos setores mais conservadores do franquismo. ${ }^{30}$

Tais concessões iniciaram-se durante o processo de negociação da transição. O franquismo colocara como condição para a retomada da democracia a manutenção da monarquia, o que foi aceito pela oposição, desde que a Coroa não tivesse prerrogativas políticas. As razões desse acordo são explicitadas em uma declaração de voto do representante comunista, Solé Tura:

Nós também éramos partidários, e assim o expressamos ao largo desses anos, de que a Constituição da forma de governo tinha que ser decidida por um referendo próprio e específico. Mas isso exigia umas condições que não se deram. Essas condições eram, para nós, aquelas sintetizadas pelo conceito de ruptura, e essa ruptura, que não se obteve fundamentalmente pelas carências da própria oposição democrática, nos coloca diante de uma situação em que a ruptura tem outras conotações e em que o referendo sobre a forma de governo, que nós queríamos anterior à Constituição democrática, coincide com esta. [...] Hoje o que divide os cidadãos deste país, fundamentalmente, não é a linha divisória entre monárquicos e republicanos, mas entre partidários da democracia e inimigos da democracia. [...] Se queremos que essa democracia funcione, necessitamos que se incorporem a ela forças políticas, institucionais fundamentais que hoje se estão incorporando de uma maneira lenta, mas progressiva - e quero saber que segura -, através precisamente da instituição monárquica. [...] enquanto a monarquia respeite a Constituição e a soberania popular nós respeitaremos a monarquia. ${ }^{31}$ 
Em dois outros temas, encontramos bons exemplos de como o acordo baseado em concessões mútuas permite chegar a uma votação consensual. Nos debates sobre a pena de morte, vários partidos posicionaram-se a favor de sua total abolição. Na Comissão Constitucional, duas posições se enfrentaram: para a AP e a UCD, essa matéria não deveria ser tratada na Constituição, mas sim na lei; ${ }^{32}$ para os abolicionistas essa era uma decisão que não poderia deixar de ser tomada pela Constituinte. ${ }^{33}$

Nessa questão, nota-se como a busca de um acordo oscila entre a concessão e a não-decisão. Após a derrota da proposta de abolição, as declarações de voto dos vitoriosos tentam convencer os grupos contrários à pena de morte a adiarem a solução do conflito para não prejudicarem o consenso constitucional. Segundo Herrero de Miñon (UCD), "Há muitas coisas que todos consideramos importantes; há muitas coisas que todos consideramos desejáveis e, sem embargo, não acreditamos que a Constituição seja o lugar adequado para estabelecê-las, pelo caráter especialmente rígido e absoluto dos termos constitucionais, que não permitem as matizações adequadas". ${ }^{34}$ Em contrapartida, a esquerda insistia na necessidade de tomar uma decisão sobre a matéria, tal como defendeu o futuro Presidente do Governo, Felipe González (PSOE):

[...] damos muita importância às questões da economia, mas nos parece que são temas sobre os que cabe chegar a uma transação, a uma negociação, como ocorre quase sempre em temas dessa natureza. Sem embargo, não é equiparável o comparável, como se fez aqui, o problema do modelo econômico com o problema se há ou não abolição da pena de morte. ${ }^{35}$

Os debates se encerraram com uma grave advertência de Solé Tura (PCE-PSUC), de que se estava colocando em risco a política do consenso:

Considero que perdemos uma grande ocasião para afirmar solenemente no texto constitucional algo que é também fundamental [...] A Constituição tem que servir para criar um sistema que funcione, mas também tem que servir para enunciar princípios nos quais queremos assentar este funcionamento democrático. Por isso, era fundamental que a abolição da pena de morte figurasse no texto constitucional. Há também outra questão que me preocupa. Debatemos entre ontem e hoje temas como o direito de asilo, como a maioridade e agora a pena de morte que são questões importantes, mas seguramente tampouco decisivas para a arquitetura do texto constitucional. Sem embargo, em todas elas nos estamos introduzindo lentamente em um terreno de conflitividade que vai-se resolvendo pelo jogo mecânico de maiorias e de minorias que não nos leva a lugar algum. ${ }^{36}$ 
Essa advertência dos defensores da abolição, no Plenário, acabou forçando a UCD a modificar sua posição, apresentando no Plenário do Congresso dos Deputados um emenda in voce nos seguintes termos: "Queda abolida la pena de muerte, salvo lo que puedan disponer las leyes penales militares para delitos cometidos por personas sujetas por su propia condición al fuero castrense". ${ }^{37}$ Assim, obtinha-se a abolição pretendida, o que representava uma concessão da UCD, ao mesmo tempo em que os setores abolicionistas aceitavam que a legislação estabelecesse a pena de morte na jurisdição militar. O compromisso aparece claro em García Añoveros (UCD): "Gostaríamos que pudéssemos obter, como utopia possível neste momento, um apoio para o texto que propomos". ${ }^{38}$ Os termos do acordo foram aceitos pelos demais partidos, à exceção da AP, que se absteve.

A votação do direito de propriedade também resultou de concessões mútuas. $\mathrm{Na}$ discussão no Plenário do Congresso dos Deputados, a AP tentou restaurar o texto original do informe da Ponencia, que trazia a exigência de indenização prévia em casos de desapropriação. O artigo havia sido alterado durante as negociações que precederam as votações na Comissão Constitucional, levando ao protesto da AP, que considerava que essa era uma questão fundamental, na qual não poderia haver concessões, como expõe seu representante De La Vallina Valverde:

Compreendo e compartilho que devemos nos esforçar todos para fazer uma Constituição ampla, flexível, que permita acolher nelas quantos mais, melhor, que permita governar a distintas forças políticas; mas tratando-se de direitos fundamentais, como é o de propriedade, não podem caber ambigüidades. ${ }^{39}$

Ao contrário do exemplo da pena de morte, essa advertência não foi considerada pelos partidos majoritários, que acordaram o seguinte texto, correspondente ao art. 33.3 da CE: "Nadie podrá ser privado de sus bienes y derechos, sino por causa justificada de utilidad pública o interés social, mediante la correspondiente indemnización y de conformidad con lo dispuesto por las leyes". Assim, a esquerda aceitou o reconhecimento do direito à indenização, enquanto a direita abriu mão da indenização prévia. ${ }^{40}$

Sem embargo, nesse acordo aparecem interpretações distintas sobre o texto aprovado. Apesar de ambos saudarem o consenso, a declaração de voto do representante socialista, Fajardo Spínola, destaca que:

Este conceito de propriedade privada, talvez em 1931 não teria sido possível; o foi, mas depois de um longo debate. Hoje, no entanto, foi muito fácil o parto do artigo 31, precisamente porque duas organizações políticas confluíram com seu bom senso em torno a um articulado que as conquistas jurídicas já haviam conseguido. ${ }^{41}$ 
Já o representante da UCD, Meilan Gil, afirma que o artigo não desmistificava a propriedade, como dissera o representante socialista, mas vinha apenas:

[...] constitucionalizar uma realidade vigente na legalidade ordinária e na doutrina e sobretudo na realidade social. [...] A palavra "mediante" há que colocá-la em relação com a expressão ”conforme o disposto nas leis".

Em termos finais, isto é o que se faz no nível constitucional, deixando à flexibilidade da legislação ordinária que se determine o que aqui está descrito de uma maneira abstrata, a atual redação não impede em absoluto que esse ”mediante” se traduza por "o prévio pagamento" - que será a regra geral numa lei de expropriação forçada na qual se garanta realmente o respeito à propriedade privada, adequando-a às circunstâncias nas quais se joga o interesse público que justifica a expropriação. ${ }^{42}$

Essa divergência de interpretação manifesta-se mais claramente em outras ocasiões, em que podemos identificar o uso de fórmulas de compromisso para lograr o acordo.

No item referente ao planejamento público da economia, opunham-se duas propostas. Desde os debates da Comissão Constitucional, a AP defendia que o planejamento fosse declarado apenas indicativo para o setor privado e, do mesmo modo que na votação sobre desapropriação, apresentava a questão como inegociável. De acordo com Fraga:

Se existe algo em que estão de acordo todos os teóricos das Constituições é que isso é um conjunto de decisões ou de normas fundamentais, e que entre elas figura justamente o modelo econômico-social. [...] De modo que essa decisão é transcendental, é a mais importante de todas, e realmente se sobre ela não se toma decisão na Constituição (seja ideologizada ou desideologizada), é como dizer que a Constituição terá um único artigo e, segundo quem governe (como naqueles regimes em que a rua é de que manda), seguir-se-á um modelo econômico ou outro. Isso não é fazer uma Constituição. ${ }^{43}$

A fórmula vitoriosa, que aparece no art. 131.1 da CE, dispõe que: "El Estado, mediante ley, podrá planificar la actividad económica general para atender a las necesidades colectivas, equilibrar y armonizar el desarrollo regional y sectorial y estimular el crecimiento de la renta y de la riqueza y su más justa distribución."

O caráter de compromisso dessa fórmula aparece nas divergências sobre a interpretação desse texto apresentadas pelos grupos que o apoiaram. Assim, quando o representante da UCD, Alierta Izuel, rebate a emenda defendida pela AP, ele destaca que a Constituição já havia tomado uma série de decisões, tais como a liberdade de empresa, a liberdade de profissão e a negociação coletiva, que, conjuntamente, excluíam um modelo econômico de planificação centralizada: 
[...] a interpretação que deve dar-se a este artigo no contexto da Constituição, e que nosso Grupo de União de Centro Democrático interpreta, é que a planificação que se recolhe nele e que estamos debatendo não será em nenhum caso coativa e em todo caso poderia assimilar-se ao que vem se definindo ultimamente pelo setor privado como planificação indicativa. ${ }^{44}$

Essa ênfase não é compartilhada pelos socialistas, tal como se infere da declaração de Pons Irazazabal:

Devemos deixar o texto aberto para que, ante uma eventual insuficiência da planificação indicativa, possam ser abordadas outras fórmulas mais eficazes para o cumprimento dos fins concretos que assinala o próprio art. 125. E eu diria que não se trata de constitucionalizar a planificação indicativa nem a planificação vinculante. Nisso discordamos da interpretação que o Sr. Fraga manteve aqui e que já manteve na Comissão Constitucional. Trata-se de fugir, junto com outros artigos do texto constitucional, da fixação rígida de um modelo econômico e social. Nós entendemos - e o temos repetido até a exaustão - que esta Constituição deve ser de uso alternativo e que não deve fixar rigidamente um modelo econômico e social. O art. 125 inscreve-se em uma série de previsões prudentes que permitirão que perdure o sistema de democracia política plasmado na Constituição, ao compasso das transformações que a evolução econômica e social demande, sem que isso obrigue pôr em questão a própria Constituição ou o sistema político. [...] Qualquer medida na qual se contivessem normas vinculantes para um setor, com o fim de encaminhá-lo à consecução de objetivos predeterminados, poder-se-ia denunciar como anticonstitucional, se tivessem sido admitidas as emendas apresentadas a este artigo. [...] A margem de incerteza que existe é ineliminável em uma sociedade politicamente plural. ${ }^{45}$

Em outro dos temas mais polêmicos da Constituinte espanhola, referente ao direito à educação, o consenso também foi obtido por meio de uma fórmula de compromisso. Na Comissão Constitucional, tal como acontecera nos casos anteriores, a AP critica a busca de acordo e insiste que a Constituição não deixe margens à legislação ordinária. ${ }^{46}$ Um dos pontos de discórdia era a insistência da AP de que se incluísse a liberdade de gestão das instituições privadas, o que foi refutado por Alzaga (UCD):

O termo "gestão", é verdade, não está recolhido literalmente [...] no último texto que elaboramos do art. 26 que vai ser objeto de votação, introduziu-se um apartado importante ao número 1 do mesmo onde se diz que se reconhece 
a liberdade de ensino. E a liberdade de ensino tem um conteúdo suficiente cunhado pela doutrina, como o tem também o direito de reunião, o direito de associação, a liberdade de imprensa e tantas outras, sem necessidade de explicitar em um texto constitucional os ingredientes que vem a compor essa liberdade. A doutrina entende por liberdade de ensino a liberdade de fundar centros docentes, de dirigi-los, de gestioná-los, de escolher professores, de fixar, quando couber, um ideário do centro; a liberdade de ministrar nos mesmos, no caso de que se considere pertinente pelos padres e os diretores do centro, a formação religiosa, etc. ${ }^{47}$

No Plenário, a declaração de voto do Grupo Socialista foi feita por Gómez Llorente:

Entendemos que esse artigo era o artigo possível nesses momentos, de acordo com o atual estado da consciência coletiva das forças políticas e sociais de nosso país. Era o texto que podia encontrar o necessário consenso, isto é, que podia expressar o denominador comum do pensamento, ao menos da imensa maioria dos Grupos Parlamentares. E logo insistirei que este artigo não recolhe a filosofia socialista da educação, a filosofia específica e particular que nós gostaríamos de manter. Mas tal como ocorre com outros muitos artigos da Constituição, e dada a natureza da empresa histórica que estamos tentando realizar, isso é perfeitamente lógico para que a Constituição seja sobretudo duradoura. ${ }^{48}$

Mas o exemplo paradigmático de fórmula de compromisso refere-se ao tema mais polêmico da Constituinte espanhola: a organização territorial do poder. O Estado espanhol formara-se no início da Idade Moderna mantendo várias prerrogativas de suas unidades, o que explica a diversidade lingüística e cultural presentes em sua história. A partir do século XIX, o ideário burguês passou a pregar maior centralização do Estado, levando à abolição daquelas prerrogativas. Isso levou ao surgimento de correntes políticas nacionais, que reivindicavam o retorno de suas autonomias, particularmente em duas regiões de grande importância econômica: Catalunha e País Basco. Sob a Constituição de 193, essas regiões tiveram o reconhecimento de sua autonomia, a qual foi posteriormente suprimida pelo regime franquista, fazendo com que as correntes nacionalistas reaparecessem com força no processo constituinte.

O compromisso entre centralismo e autonomia verifica-se nos próprios termos do art. $2^{\mathrm{O}}$ da CE, que dispõe: "La Constitución se fundamenta en la indisoluble unidad de la Nación Española, patria común e indivisible de todos los españoles, y reconoce y garantiza el derecho a la autonomía de las nacionalidades y regiones que la integran y la solidaridad entre ellas". 
Para o Deputado da UCD, Arias-Salgado, na votação desse artigo:

Encontramo-nos, sem dúvida, diante de um dos preceitos mais polêmicos do texto constitucional e de mais difícil elaboração consensual. [...] Entendemos que a redação última da Ponencia tem defeitos e é imperfeita. Mas, como fórmula de compromisso, parece-nos suficiente porque é susceptível de dar satisfação bastante às nacionalidades e regiões e porque marca claramente os limites infranqueáveis do princípio de seu direito à autonomia. ${ }^{49}$

A tentativa de conciliar a "unidade da nação espanhola" com as "nacionalidades" que a integram só podia dar margem a interpretações divergentes. Ainda para Arias Salgado:

O termo "nacionalidades" do art. $2^{\mathrm{O}}$ implica, simplesmente, o reconhecimento da existência de formações sócio-históricas às quais se confere um direito à autonomia, cujo limite de princípio infranqueável reside precisamente na soberania da unidade política que as compreende e cujo limite de conteúdo se concretiza normativamente no articulado do próprio texto constitucional. ${ }^{50}$

Já para o representante da Minoria Catalã, Roca Junyent, a ênfase é outra:

[...] Espanha é uma realidade plurinacional e essa realidade pode ser perfeitamente assumida em uma Constituição que, ao lado de definir essa nação espanhola, nação-Estado, define aquelas outras nacionalidades que são aquelas identidades históricas e culturais [...] As autonomias são forma de participação no poder político e não supõem, em absoluto, nada que degrade nem que desagregue o poder do Estado, porque são também parte do poder do Estado e, portanto, do que se trata é de distribuir esse poder público. ${ }^{51}$

De modo coerente com essa fórmula de compromisso, a repartição de competências entre o Estado e as Comunidades Autônomas (CCAA) deixou uma ampla margem à regulação infraconstitucional, incluindo a elaboração dos Estatutos de Autonomia, no qual estariam definidas as competências assumidas pelas CCAA (art. 147). ${ }^{52}$

\subsection{NÃO-DECISÃo}

Em outras ocasiões da Constituinte espanhola, a dificuldade de chegar a um acordo substantivo sobre determinada questão levava os principais partidos a não tomarem uma decisão sobre ela, adiando a solução do conflito para a legislação infraconstitucional, à qual caberia integralmente a regulação da matéria.

O exemplo mais típico dessa opção é a votação sobre o divórcio. Não havendo acordo em torno de sua aprovação, o texto constitucional foi redigido da seguinte 
maneira: "La ley regulará las formas de matrimonio, la edad y capacidad para contraerlo, los derechos y deberes de los cónyuges, las causas de separación y disolución y sus efectos" (art. 32.2). Apesar dos Deputados da AP considerarem que essa redação constitucionalizava o divórcio, e terem apresentado emendas ao texto para suprimir a referência à dissolução do matrimônio, o texto não vinculava o legislador a optar pelo divórcio como forma de dissolução, deixando "aberta a porta para que o legislador ordinário possa resolver sobre esta questão de acordo com o que possa entender como mais adequado à realidade social a que pretende dirigir-se", tal como expôs Roca Junyent (Minoria Catalã). ${ }^{53}$ Para Solé Tura (PCE-PSUC), a desistência da proposta de constitucionalização do divórcio pelos comunistas, justificava-se para "tentar resolver da maneira mais equilibrada possível os temas de princípio, temas em que, evidentemente, é difícil pôr de acordo forças tão distintas como as que aqui estamos representadas". ${ }^{54}$

Outro exemplo de não-decisão encontra-se na composição do Conselho Geral do Poder Judiciário (CGPJ). Desde os trabalhos da Ponencia, não foi possível chegar a um acordo sobre o direito dos juízes elegerem diretamente membros da categoria para o CGPJ, proposta defendida pela esquerda. Assim, a Constituinte não se pronunciou sobre a matéria, recusando também uma emenda apresentada pela AP que proibia essa eleição pelos membros da Magistratura.

\subsection{MAIORIA ARITMÉTICA}

Por fim, em poucas ocasiões a votação na Constituinte espanhola não incorporou os principais grupos políticos, baseando-se em uma maioria aritmética. Tal ocorreu na votação do art. 16.3, que fazia referência expressa à Igreja Católica e teve a oposição dos socialistas: "Ninguna confesión tendrá carácter estatal. Los poderes públicos tendrán en cuenta las creencias religiosas de la sociedad española y mantendrán las consiguientes relaciones de cooperación con la Iglesia Católica y las demás confesiones".

Essa menção à Igreja Católica fora acrescentada no informe da Ponencia, contra a posição socialista, comunista e catalã. A proposta foi da UCD, que era menos enfática que aquelas apresentadas pela AP. Na Comissão Constitucional, Fraga (da AP) realçou que esse era um dos artigos mais importantes da Constituição, e que seria bom que fosse aprovado com o "máximo consenso", 55 apelando à esquerda que cedesse nesse ponto. Apesar de o Partido Comunista ter votado a favor, os socialistas não aderiram à proposta, justamente por considerarem que ela não era consensual, tal como expôs Peces-Barba:

Somos contra essa menção não justificada porque, de alguma maneira, rompeu a tentativa que se fez de estabelecer um consenso. [...] fizemos neste tema, como em muitos temas já votados com anterioridade, um enorme esforço para chegar a fórmulas que assegurem uma vida tranqüila, pacífica e séria a esta Constituição. ${ }^{56}$ 
Outro exemplo de maioria aritmética deu-se na discussão sobre o direito à sindicalização dos juízes, reivindicação de socialistas e comunistas que não foi admitida pela UCD, e na votação sobre a composição do Senado, na qual o acordo entre a UCD e os Socialistas não incorporou os Comunistas e as minorias basca e catalã, que defendiam que a circunscrição eleitoral dos Senadores fosse constituída pelas Comunidades Autônomas, com representação proporcional, e não pelas Províncias, como acabou prevalecendo.

O pequeno número de decisões tomadas na Constituinte espanhola por maioria aritmética não teve grande repercussão sobre a estabilidade constitucional. Somente a questão da composição do Senado continua sendo alvo de debates constitucionais na Espanha, acompanhando o tema da organização territorial do poder.

\section{Os ACORdos NA Constituinte BRASileira 57}

A convocação de uma Assembléia Constituinte era um dos pontos do Programa da "Aliança Democrática", acordo político que reunira setores da oposição e do regime para promover a transição do regime autoritário, após a derrota da proposta de emenda constitucional que convocava eleições diretas para a sucessão do General. João Batista Figueiredo. Vitorioso o candidato da AD, Tancredo Neves, no Colégio Eleitoral, o governo civil assume em março de 1985, sob o comando de seu vice, José Sarney, tendo em vista os problemas de saúde que acometeram Tancredo e acabaram levandoo à morte. Em novembro de 1985, após um longo processo de negociação, foi promulgada a Emenda Constitucional n. 26, à Constituição de 1967, conferindo poderes ao Congresso Nacional que seria eleito em novembro de 1986, para aprovar a nova Constituição em reunião unicameral, por maioria absoluta. ${ }^{58}$

A Constituinte brasileira iniciou-se com uma extensa polêmica sobre seu Regimento, no qual explicitou-se inclusive a divergência sobre o caráter originário ou derivado do poder constituinte que seria exercido. ${ }^{59}$ As divergências internas dos partidos também se manifestaram logo no início dos trabalhos. Antes mesmo da discussão do Regimento, alguns Deputados do PMDB questionaram que as normas provisórias tivessem sido definidas somente pelas lideranças, que vinham da legislatura anterior, ainda que de modo consensual. O Deputado Tidei de Lima (PMDB) pregou que não deveria haver voto de liderança na Constituinte e ironizou:

Creio que são necessárias pelo menos 24 horas para sugerir alguma correção, ou incluir alguma medida, apesar de entendermos que os líderes são os luminares com grandes conhecimentos, são quase infalíveis. Mesmo assim podem, por um momento ou outro, ser falíveis. Gostaríamos, humildes mortais desta planície, de ter 24 horas para tomar conhecimento das normas provisórias, a fim de sugerir alguma coisa que possa até embasar o regimento definitivo. ${ }^{60}$ 
A discussão do Regimento também foi bastante polêmica, como comprovam as 949 emendas apresentadas ao projeto e o episódio ocorrido na sessão de 25.02, em que a bancada aliada ao Governo retirou-se do Plenário para inviabilizar sua votação. ${ }^{61}$ As principais divergências incidiam sobre os poderes que a Assembléia Constituinte teria - especialmente se ela poderia promulgar "projetos de decisão" e se o Congresso Nacional teria funcionamento regular - bem como sobre a convocação de um referendo popular para aprovação da Constituição.

As dificuldades de aprovação do Regimento demonstraram que os líderes do PMDB não tinham controle sobre sua bancada, o que os obrigava a negociar com o PFL e o PDS. Del Bosco Amaral expressa essa posição da base do PMDB, dizendo que seus membros votam de acordo com suas consciências: “(...) estou à vontade para votar fora de minha bancada na Constituinte, quando sentir que existem interesses anti-nacionais, para não usar a expressão "subalternos". ${ }^{62}$ Ao final da sessão, o líder do PFL, José Lourenço, assim se manifestou: "[...] aqui não existem vencidos, nem vencedores. [...] Mais do que nunca ficou provado hoje que só através do entendimento político conseguiremos resultados que vão ao encontro da vontade da Nação". 63

Finalmente, na sessão de 10.04, o Regimento foi aprovado em votação simbólica, ressalvados os destaques. Os projetos de decisão foram restringidos em troca da aceitação das emendas populares, da redução de quorum para destaque e da limitação do funcionamento da Câmara e do Senado.

Assim como na Espanha, vemos que o processo constituinte brasileiro foi desenvolvido com base no acordo entre os grupos políticos. O número alto de votações não consensuais, contudo, indica maiores dificuldades para lograr esses acordos, tal como veremos a seguir.

\section{I Concessões mútuas}

O melhor exemplo de concessões mútuas na Constituinte brasileira encontra-se nas votações do capítulo referente aos direitos individuais. De início, foi aprovada a emenda coletiva do Centrão ao Capítulo I do Título II do Projeto “A”, que recebeu o apoio do PMDB, PDT, PL, PDC, PCB e PTB, em troca da concordância com a modificação de vários de seus dispositivos. Por outro lado, restou a irresignação do PT, PSB e PCdoB, sobretudo em relação ao atendimento de certas demandas consideradas como princípios prévios, sem os quais o acordo não era possível. Além disso, mesmo para aqueles que integraram o acordo, alguns pontos surgiram como inconciliáveis, sendo remetidos à decisão no momento da votação em Plenário.

Para os partidos que compuseram a maioria, o acordo que garantiu o entendimento em torno da aprovação da emenda do Centrão envolveu concessões mútuas, como exemplificou a fala de Gastone Righi (PTB): 
São poucos, muito poucos os pontos em que divergimos. E hoje viveremos um acordo, uma composição, que não se fez total ou global, mas que atinge um espectro tão largo da matéria que vamos votar que se poderia dizer que representa um consenso tranqüilo do pensamento desta casa. Iremos, por consenso, aprovar o substitutivo dito do "Centrão"'. Aceitaram os membros do "Centrão" com os de outras correntes que ou a nós se agregaram, ou caminham paralelamente a nós, como o grupo dos 32, o Centrinho, o PMDB, o PDT e tantos outros. E nos entendemos para fazer mais de trinta modificações no substitutivo, modificações que vão desde as redacionais, até as de fundo, as de conceito [...] Assim, as lideranças concordaram com trinta modificações e com o direito democrático de haver destaques e de irmos para Plenário para a discussão. ${ }^{64}$

Referindo-se somente ao capítulo dos direitos individuais e coletivos (Título II, Capítulo I), Roberto Freire (PCB) esclareceu a lógica da negociação:

Basta atentar para um detalhe: são mais ou menos 60 parágrafos e algumas emendas aditivas. Todos os partidos aqui representados, sem exceção, inclusive os blocos, apresentaram destaques para 26 desses parágrafos. Quanto aos demais, todos nós admitíamos que era um texto democrático. Com a negociação, desses 26, 20 representaram avanços democráticos”. 65

Da mesma forma, a manifestação de Mário Covas (PMDB):

Sr. Presidente, devo dizer aos companheiros que a liderança participou de um acordo com as demais lideranças, e em princípio fixou o seguinte: uma reforma regimental. E a Assembléia é testemunha de que esta liderança manifestou-se contra tal reforma. Todavia, pela vontade da maioria, ela ocorreu. Portanto, as regras de funcionamento desta Casa são decorrentes da mudança regimental. Nessas condições, ouvindo os companheiros, a liderança houve por bem concordar com a votação do substitutivo, apresentado pelo "Centrão". Em contrapartida, obtivemos do "Centrão” concordância no que diz respeito às 22 das 27 reivindicações feitas pelo PMDB. ${ }^{66}$

Contudo, os depoimentos já demonstravam que a negociação não agregara todos os partidos, nem obtivera consenso sobre todas as matérias. Ao se manifestarem, os líderes partidários enunciavam o elenco das questões que seriam decididas em plenário, porque delas não se abriria mão. O PMDB, por exemplo, destacou cinco reivindicações não atendidas pelo Centrão as quais iria disputar em Plenário: 
Esses pontos referem-se aos $\S 8^{O}$ - (É livre a locomoção no território nacional em tempo de paz...), $9^{\circ}$ (tortura) e 38 (asilo político) - Da Propriedade ao parágrafo que permite às entidades representarem em juízo ou fora dele os seus filiados e, finalmente, o mandado de segurança coletivo. São os itens que disputaremos nos votos em Plenário. Quanto aos demais, votaremos em conjunto, o mais breve possível. 67

Além disso, outros partidos se colocaram à margem da negociação, criticando-a principalmente por haver promovido mudanças conservadoras ao texto da Comissão de Sistematização e por não ter garantido vários direitos aos trabalhadores. ${ }^{68}$

A necessidade de concessões mútuas para chegar a um acordo aparece com maior nitidez na discussão do $§ 39$, art. $6^{\circ}$, da emenda do Centrão ao Título II. Conforme havia anunciado o líder Mário Covas, o PMDB requereu destaque para a votação em separado - que exigia maioria absoluta para aprovação - do seguinte texto:

$\S 39$ - É assegurado o direito de propriedade. A lei estabelecerá o procedimento para a desapropriação por necessidade ou utilidade pública ou por interesse social, mediante justa e prévia indenização em dinheiro. Em caso de perigo público iminente, a autoridade competente poderá usar propriedade particular, assegurada ao proprietário indenização ulterior se houver dano.

Em conjunto com PDT, PT, PCB e PCdoB, o PMDB derrubou o texto por 248 votos contra 236 votos. Contudo, as emendas apresentadas para substituir a proposta do Centrão também foram rejeitadas, gerando um "buraco negro". Aplicando o Regimento, o relator apresentou uma proposta conciliadora alcançada após sucessivas reuniões das lideranças:

É garantido o direito de propriedade. A propriedade atenderá sua função social, a lei estabelecerá o procedimento para desapropriação por necessidade e utilidade pública ou por interesse social, mediante justa e prévia indenização em dinheiro, ressalvados os casos previstos nesta Constituição. Em caso de perigo público iminente a autoridade competente poderá usar propriedade particular, assegurado ao proprietário indenização ulterior, se houver dano.

Nos termos do acordo, a esquerda aceitou a consagração do direito de propriedade e da indenização em dinheiro em troca da aceitação, pela direita, do princípio da função social da propriedade e das exceções à indenização para fins de reforma agrária e urbana. 69

A emenda foi aprovada por ampla maioria (446 votos "sim", 40 votos “não", e 4 abstenções). Contudo, PT, PCdoB e PSB votaram contra, pois haviam eleito como 
ponto inegociável excluir do texto constitucional a fixação do dinheiro como forma de pagamento das indenizações, além de considerarem que não havia garantia de que o Centrão como um todo honraria os compromissos de aprovar os demais dispositivos objeto do acordo.

\subsection{NÃO-DECISÃO E MAIORIA ARITMÉTICA}

Ao contrário do processo espanhol, em que o recurso à não-decisão gera, na maioria das vezes, uma votação consensual, na Constituinte brasileira não é possível identificar essa relação em várias matérias importantes. Nesse caso, o adiamento da solução do conflito para a legislação infraconstitucional não é aceito por minorias relevantes, o que acaba gerando uma decisão por maioria aritmética.

Esse problema aparece logo na discussão do Capítulo II do Título II, referente aos direitos sociais. Já na votação da emenda substitutiva do Centrão a esse capítulo, o número de votos contrários (163) foi bem maior do que na votação do Capítulo I (56). A discordância estava presente mesmo entre os partidos que indicaram a aprovação da emenda substitutiva, como se manifesta nas declarações dos líderes do PMDB e do PTB: o primeiro afirma que haverá disputa de votos em vários pontos; o segundo repudia o tratamento dado à estabilidade no emprego. ${ }^{70}$

As dificuldades para fazer acordos à esquerda e à direita nessa matéria são exemplificadas por duas votações específicas.

O texto do substitutivo do Centrão dera o seguinte tratamento às horas extras: "Serviço extraordinário com remuneração cinqüenta por cento acima do normal ou conforme convenção ou acordo coletivo". A partir de emenda substitutiva, negociada entre PMDB, PFL, PDS e PTB, o texto assumiu o seguinte teor: "Serviço extraordinário com remuneração no mínimo superior em cinqüenta por cento à da normal”.

A esquerda considerou esse acordo um retrocesso diante do que se tinha alcançado na Comissão de Sistematização, que estabelecia remuneração da hora extra em cem por cento, valor que já era concedido pelos tribunais em litígios trabalhistas. Ademais, argumentava-se que aumentar o valor da hora extra ampliaria a proteção ao trabalhador, forçaria novas contratações e diminuiria os riscos de acidente de trabalho.

Para os defensores da emenda, o valor de cinqüenta por cento representava um piso, e não um teto que congelasse a remuneração da hora extra. Asseguravam que a vantagem de fixar esse piso encontrava-se em proteger os trabalhadores carentes de organização, que teriam garantido constitucionalmente o valor mínimo. A votação da matéria não pode ser enquadrada como consensual: 307 votos "sim", 112 votos "não", e 3 abstenções.

Assim como o acordo sobre as horas extras não abrangeu a esquerda, o acordo sobre a jornada de trabalho em turnos de revezamento não abrangeu a direita. $\mathrm{O}$ texto do art. $8^{\mathrm{O}}$, XIII, do substitutivo do Centrão, dispunha: "Jornada especial de trabalho para turnos de revezamento, ininterruptos, conforme convenção ou acordo 
coletivo”. A emenda substitutiva, apresentada por PMDB, PT e PCdoB, propunha: "Jornada máxima de seis horas para o trabalho realizado em turnos ininterruptos de revezamento, salvo negociação coletiva”.

A defesa da emenda argumentou sobre os efeitos: (i) preserva a saúde, bem-estar e condições de vida digna do trabalhador, o que dá à matéria status constitucional; (ii) estabelece as seis horas máximas como regra geral pelo benefício dos trabalhadores que não são favorecidos com os acordos e convenções coletivas; e (iii) não traz grandes ônus para o faturamento da empresa.

Os turnos contra a emenda destacaram os efeitos negativos: (i) impor arbitrariamente o limite da jornada é descapitalizar o trabalho e limitar a margem de atuação dos sindicatos; e (ii) ao estabelecer no texto constitucional o máximo de seis horas, seria demagogia dizer que por meio de negociação ou acordo se pode ampliar esse período.

O PDT, o PTB e o PDC encaminharam voto "sim"; ao passo que o PDS e o PFL lideravam os votos "não". Como proposta conciliadora, o relator propôs que os autores da emenda, no segundo turno, se comprometessem a apresentar uma emenda supressiva ao termo "máxima", onde residiria o âmago das divergências, proposta aceita pelos autores da emenda, mas negada por seu contraditores, o que justifica os 125 votos contra.

Segundo João Paulo (PT): "Os autores da emenda diante da exposição do nobre relator, estão acordes em apresentar um destaque supressivo retirando a palavra “máxima”. No mesmo sentido, Mário Covas (PMDB):

Há duas maneiras de agirmos numa Casa como esta, num instante como este. Há as fórmulas definitivas e há os compromissos futuros. Em vários acordos aqui feitos, temos fixado compromissos que só serão cumpridos no futuro. A emenda que ora se vai votar tem dois patronos: O Constituinte que acabou de anunciá-la [...] e que se propõe a tirar a palavra mais adiante. ${ }^{71}$

Essas promessas não foram aceitas pelo Centrão. Para Luís Roberto Ponte (PMDB):

[...] falando aqui na possibilidade de retirada de uma palavra, que V. Exa. diz não ser possível nesta fase, mas somente na segunda. Não há nada mais lógico, se essa intenção, se isso resolver, acho que devemos meditar se isso realmente resolve, não é nesse afã e nessa correria que vamos decidir isso. Qual é o instrumento lógico? O instrumento lógico é deixarmos um buraco negro provisório para negociarmos serenamente, completando as nossas informações para não criarmos o caos neste País. Por isso sugerimos que a votação seja não”. ${ }^{72}$

A discussão sobre a estabilidade no emprego também aparece como uma das mais polêmicas no capítulo dos direitos sociais e exemplifica as dificuldades para 
obter acordos nessa matéria. O substitutivo aprovado com a emenda coletiva do Centrão fixou como texto base: "Estabilidade no emprego, após doze meses, mediante garantia de indenização correspondente a um mês de salário por ano de serviço prestado, nos casos de demissão sem justa causa e, nos casos de força maior, de indenização na forma da lei”.

Aprovado o substitutivo, duas emendas de fusão visaram alterá-lo. A primeira, de autoria do PT, PDT, PCB, PCdoB, PSB e uma parcela do PMDB, estabelecia: "Relação de emprego protegida contra a despedida arbitrária ou sem justa causa definida em lei, com nulidade do ato de demissão e os casos de indenização, sem prejuízo de outros direitos".

A segunda, resultante do acordo entre PFL, PDS e outra parcela do PMDB, propunha: "Relação de emprego protegida contra despedida arbitrária ou sem justa causa, nos termos de lei complementar que preverá indenização compensatória, dentre outros direitos".

O ponto comum de todas as propostas de correção da emenda coletiva centravase na existência de indenização. Domingos Leonelli (PMDB), referindo-se à proposta dos partidos menores de esquerda, afirmou: "Nesta nossa emenda está o que os empresários do ‘Centrão' exigiram desde o começo, e aquilo a que a esquerda resistiu no início, que é exatamente a inclusão da indenização no texto permanente". ${ }^{73}$ No mesmo sentido, o pronunciamento de Mário Covas: "Não conheço qualquer emenda que, de alguma forma, não tenha falado em indenização. Nem a do companheiro Lula, que também a contempla, embora a critério do trabalhador". ${ }^{74}$

Dentre as propostas, apenas a última foi discutida e debatida, pois sua aprovação prejudicou as demais. Em sua manifestação, Mário Covas argumentou que ela trazia grandes ganhos em relação ao mínimo que se havia estabelecido, alegando, ao fim, que o que estava para ser aprovado era o máximo suportável dentro da bancada do partido:

Por outro lado, não é menos verdade que a posição do “Centrão” e dos setores mais conservadores da sociedade brasileira, aqui, foi sempre a de vincular a relação de emprego a uma única coisa: a indenização. Essa sempre foi a exigência contida em tudo aquilo que se possa identificar como emendas originárias desse setor. [...] O “Centrão" defendeu a seguinte posição: garantia de emprego, garantia através da indenização. Recebi, neste intervalo, proposta subscrita por setores sindicalistas que merecem o maior respeito. O que dizem esses setores? Que seriam capazes de ir até o seguinte limite: 'Relação de emprego protegida contra despedidas arbitrárias ou sem justa causa na forma da lei, que disporá sobre a nulidade do contrato de demissão e sobre casos de indenização’. Parece-me que falta aqui acrescentar 'e outros direitos' [...] Os sindicalistas chegaram a aceitar o seguinte limite: garantia de emprego, nos termos da lei, desde que incluída a nulidade e a indenização [...], e meu partido, a Comissão 
de Sistematização, defendeu a seguinte posição: garantia de emprego, contra decisões imotivadas, nos termos da lei. Finalmente, consultada a bancada, chegamos a um texto julgado suportável, que não é, em hipótese alguma, nenhuma forma de desprestígio à classe trabalhadora. [...] A posição do PMDB deixava a lei em aberto. Estão estabelecidos parâmetros. De um lado, a indenização compensatória no mesmo nível dos direitos. Nem sei como isso será estabelecido. Essa é uma luta a ser travada em Lei Complementar. ${ }^{75}$

A aprovação da emenda foi assegurada dentro do limite em que o PMDB garantiu o apoio da bancada e firmou compromissos com alguns setores envolvidos. Como, da emenda aprovada, parte da decisão (indenização e outros direitos) foi repassada para a lei infraconstitucional, ainda na Constituinte os autores comprometeram-se a fazer aprovar algumas garantias para o trabalhador, com o que supriram temporariamente a inexistência de lei que regulasse a matéria. Assim, houve o compromisso de fazer aprovar no ADCT um acréscimo de dez por cento ao total do FGTS como indenização e garantir a estabilidade dos líderes sindicais, das gestantes e dos trabalhadores da Cipa (Comissão Interna de Prevenção de Acidentes).

Observa-se que, ao contrário dos dois casos anteriores, a emenda vitoriosa, resultante de fusão que expressa concessões mútuas - o Centrão admitiu o princípio da proteção da relação de emprego e as disposições transitórias sobre a matéria, e o PMDB aceitou a indenização - buscou também o caminho do acordo fundado na nãodecisão, delegando à legislação ordinária o conteúdo da proteção. ${ }^{76}$ Apesar disso, a esquerda pressionava pela nulidade da demissão e também divergia da exigência de lei complementar, o que não permitiu uma votação consensual: 151 constituintes foram contra o acordo.

A dificuldade de não decidir na Constituinte brasileira também aparece nas votações do Título VII da Ordem Econômica, provocando mais uma vez votações não consensuais. A votação do Capítulo I desse Título, referente aos princípios gerais da ordem econômica, fundara-se, no primeiro momento, em uma negociação bemsucedida, que permitiu o acordo básico sobre temas polêmicos como o conceito de empresa nacional, a nacionalização dos minérios e os contratos de risco. Assim, a Emenda coletiva ao Capítulo I, do Título VII, foi aprovada com 519 votos a favor, 9 votos contra e 6 abstenções. No entanto, permaneciam divergências sobre aspectos específicos dessas matérias, como demonstra o depoimento de Mário Covas durante os debates. ${ }^{77}$

A divergência sobre a conceituação da empresa brasileira aparecia na tentativa de inclusão do seguinte texto: "O poder público dará tratamento preferencial à aquisição de bens e serviços produzidos no País por empresas brasileiras". ${ }^{78}$

Para os deputados do Centrão, esse texto estava além dos limites da negociação, como exemplifica o Deputado Ricardo Fiúza (PFL): "O que se quer acrescentar já 
está contido no $\S 2^{\circ}$, mas não de forma cartorial. E alguns empresários que defendem a livre iniciativa querem ter seus cartórios e gozar dos benefícios da ausência de concorrência”. ${ }^{79}$ A reivindicação de que essa lei fosse complementar também não contou com o apoio da maioria, levando a uma votação não consensual, com 148 constituintes contrários à proposta.

Processo semelhante ocorreu com a votação sobre a exploração de recursos do subsolo. Nesse caso, a divergência existia quanto ao grau de nacionalização que deveria conter essa matéria, defendendo o Centrão e seus aliados a seguinte proposta ao artigo 205:

$\S 3^{\mathrm{O}}$ - O aproveitamento dos potenciais de energia hidráulica e a pesquisa e a lavra de recursos e jazidas minerais somente poderão ser efetuados mediante autorização e concessão da União, no interesse nacional. São privativos de brasileiros ou de empresas brasileiras de capital nacional o aproveitamento de potenciais de recursos hídricos e a pesquisa e a lavra de recursos minerais considerados estratégicos, na forma da lei, bem como aqueles situados em faixa de fronteira e em terra indígena, obedecida a legislação pertinente. ${ }^{80}$

A esquerda pretendia ampliar a nacionalização além do que fosse considerado estratégico, e propôs o seguinte texto, que foi vitorioso:

$\S 3^{\circ}$ - O aproveitamento dos potenciais de energia hidráulica e a lavra de recursos e jazidas minerais somente poderão ser efetuados mediante autorização ou concessão da União, no interesse nacional, por brasileiros ou empresas brasileiras de capital nacional, na forma da lei, que regulará as condições específicas quando estas atividades se desenvolverem em faixa de fronteira ou terras indígenas.

Justificou-se a emenda argumentando acerca da tradição das constituições do País de nacionalizar os recursos minerais e da importância estratégica destes, principalmente para um País de dimensões e riquezas naturais tão vastas. Contraditouse argumentando que a proposição ia contra os interesses nacionais, considerando-se sobretudo o volume de capital estrangeiro investido aqui, através desse setor, e pelo fato de a proposta não passar de um programa partidário que traía os esforços de composição de acordo realizados nas emendas anteriores. Nesse caso, também houve forte oposição: 126 constituintes votaram contra.

Como se sabe, ambas as disposições da ordem econômica foram posteriormente alteradas pela Emenda Constitucional n. 6. O mesmo destino tiveram outros artigos oriundos de votações não consensuais na Constituinte brasileira, tais como o prazo prescricional das ações trabalhistas (art. $7^{\circ}$, XXIX, alterado pela EC $n^{\mathrm{O}} 28$ ), o direito 
de greve dos servidores públicos (art. 37, VII, alterado pela EC $\mathrm{n}^{\mathrm{O}} 19$ ) e a fixação da taxa máxima de juros em doze por cento (art. 192, $\S 3^{\circ}$, alterado pela EC n. 40), que tiveram, respectivamente, 115,89 e 112 votos contrários.

\section{Conclusão}

A comparação dos dois processos indica que as maiorias na Constituinte espanhola se formaram com base em concessões mútuas, incluindo a ampla utilização de fórmulas de compromisso, bem como por meio de acordos para não tomar decisões sobre determinadas matérias, deixando sua regulação para a legislação infraconstitucional. Já no caso da Constituinte brasileira, observa-se que, em vários temas importantes, os acordos não incorporaram minorias relevantes, limitando-se a organizar uma maioria aritmética.

Essas diferenças explicam, em parte, a estabilidade dos dois textos constitucionais. Como vimos, várias votações que não contaram com amplo apoio na Constituinte brasileira resultaram em disposições que foram posteriormente alteradas por emenda constitucional ou que ainda estão pendentes de regulamentação. Em contrapartida, a Constituição Espanhola mantém-se com seu texto praticamente inalterado.

Verificadas essas diferenças, cabe ensaiar sua explicação. A dificuldade para lograr acordos na Constituinte brasileira encontra um de seus motivos na ausência de partidos disciplinados, que facilitassem a negociação e o cumprimento desses compromissos. No caso espanhol, o acordo entre os dois principais partidos, UCD e PSOE-PSC, garantia uma ampla maioria às votações, às quais se incorporaram, em quase todos os momentos, o Partido Comunista e a Minoria Catalã. No caso brasileiro, as negociações envolviam um número maior de agentes, tendo em vista que os partidos continham diferentes grupos em seu interior. A melhor expressão das dificuldades no processo de negociação aparece nas várias ocasiões em que as lideranças partidárias não tinham certeza do resultado da votação em plenário ou viam seus encaminhamentos serem rejeitados por membros de sua própria bancada. Essa incerteza servia de incentivo para que os grupos presentes na Constituinte tentassem aprovar suas propostas mesmo sem contar com o apoio das lideranças dos demais grupos.

Em segundo lugar, o processo de elaboração da Constituição influenciou de modo distinto, em cada um dos casos, o recurso às concessões mútuas e à não-decisão como estratégia de negociação e formação de maiorias. No caso espanhol, os trabalhos iniciais da Ponencia e da Comissão Constitucional limitaram o conteúdo da Constituição, em razão do pequeno número de constituintes envolvidos no debate, mas, principalmente, por neles terem sido forjados boa parte dos acordos que permaneceram na votação em Plenário. Já, no Brasil, o processo de elaboração a partir das subcomissões gerou um texto constitucional detalhado, que ampliava 
as possibilidades de desacordo no Plenário, especialmente após a substituição do projeto aprovado na Comissão de Sistematização pelas emendas do Centrão.

O reconhecimento desses fatores esclarece as formas que facilitam a obtenção de acordos constituintes. No entanto, não podemos deixar de examinar as conseqüências desses diferentes modos de formação de maiorias.

No modelo espanhol, a ausência de decisão sobre determinadas matérias ou o recurso a fórmulas de compromisso atribui à legislação ordinária e à justiça constitucional um papel decisivo na solução dos conflitos. Isso significa que o êxito dessa Constituição dependerá da continuidade do processo de negociação no plano da legislação infraconstitucional, e de uma justiça constitucional ativa no desenvolvimento do conteúdo dos acordos fundamentais obtidos no processo constituinte. No caso da Constituição de 1978, a política do consenso na legislação complementar foi favorecida pela exigência de maioria absoluta para aprovação das leis orgânicas, que deveriam regulamentar as matérias mais importantes, enquanto o Tribunal Constitucional desenvolveu uma jurisprudência criadora para tornar efetivos os preceitos constitucionais, particularmente no que se refere à organização territorial do poder. ${ }^{80}$

No modelo brasileiro, a formação de maiorias pelo critério aritmético resulta em menor indeterminação do texto constitucional, com um amplo recurso a regras, em vez dos princípios que caracterizam as fórmulas de compromisso. Contudo, essa Constituição se encontra mais sujeita a reformas caso a maioria política deixe de acatar as decisões constitucionais, como ocorreu com a Carta de 1988. Nesse modelo, o papel da justiça constitucional também será acentuado, considerando a variedade de argumentos que poderão ser utilizados para contestar a constitucionalidade das leis, mas a jurisprudência constitucional tenderá a exercer mais uma função de defesa que de criação do ordenamento constitucional.

Vale observar ainda que, mesmo votações consensuais como as que caracterizaram a Constituinte espanhola, podem não abrigar minorias expressivas. Isso ocorreu com a minoria nacionalista basca, que, à frente do governo de sua Comunidade Autônoma, continua reivindicando a soberania política. Por outro lado, também pode ocorrer que as minorias do processo constituinte, ao se tornarem maiorias políticas, tenham alterado sua valoração da Constituição. No caso espanhol, o principal grupo excluído dos acordos constituintes, a Aliança Popular, chegou ao governo espanhol em 1996, como Partido Popular, após um processo de mudanças internas que o levou a uma posição de apoio ao regime constitucional. Guardadas as diferenças, fenômeno semelhante pode ser verificado, no Brasil, com o Partido dos Trabalhadores, que votou contra o texto final da Constituição de 1988, ainda que houvesse reconhecido a legitimidade do processo constituinte ao assiná-la.

Em ambos os casos, nota-se que a estabilidade da Constituição encontra-se estreitamente associada à dinâmica democrática. No momento de sua aprovação, a 
Constituição espanhola parecia deixar um alto grau de incerteza no processo político, que foi sendo superado pela aceitação de suas normas pelos grupos políticos, situação oposta àquela vivida pela Constituição brasileira. Isso significa que o processo constituinte é apenas o ponto de partida - ainda que muito relevante - da permanente construção do consenso constitucional, ou seja, da busca do equilíbrio entre o que deve e o que não deve ser dito pela Constituição.

: ARTIGO APROVAdo (04/11/2008) : RECEBIDO EM 30/07/2008

\section{NOTAS}

1 Escritos de Derecho Constitucional (Madrid: Centro de Estudios Constitucionales, 1992, p. 69).

2 Tal como ocorreu com a aceitação da reedição indiscriminada de medidas provisórias antes da promulgação da Emenda Constitucional n. 32.

3 Cf. Antonio G. Moreira Maués, Poder e Democracia: O Pluralismo Político na Constituição de 1988 (Porto Alegre: Síntese, 1999, p. 13-17).

4 Cf. Robert Dahl, La Poliarquia. Participación y oposición (Madrid: Tecnos, 1989, especialmente p. 13-25).

5 Sobre o tema, ver Jacinto Nelson de Miranda Coutinho (Org.), Canotilho e a Constituição Dirigente (Rio de Janeiro: Renovar, 2003).

6 As tensões entre o constitucionalismo, entendido como um conjunto de limites ao poder, e a democracia, entendida como poder da maioria, é um tema recorrente do pensamento constitucional. Para muitos autores, os limites impostos pela Constituição só podem ser justificados democraticamente quando fortalecem a própria democracia, estabelecendo normas que asseguram a continuidade e a qualidade da deliberação pública. Cf. Stephen Holmes, Precommitment and the paradox of democracy. In: Jon Elster, Rune Slagstad (Eds.). Constitutionalism and Democracy. Cambridge: Cambridge University Press, 1988.

7 O processo legislativo e o exercício do controle de constitucionalidade formam também momentos fundamentais na busca do consenso constitucional. No primeiro caso, o legislador deve respeitar os acordos feitos na Constituinte e desenvolver seu conteúdo normativo; no segundo caso, a justiça constitucional deve proteger o conteúdo desses acordos, fiscalizando tanto as ações quanto as omissões do legislador.

8 Além dos citados, a Constituinte espanhola contou com a representação dos seguintes partidos (o número de parlamentares está indicado entre parênteses): Partido Comunista da Espanha-Partido Socialista Unificado da Catalunha, PCE-PSUC (20); Aliança Popular, AP (16); Pacto Democrático pela Catalunha e União do Centro e a Democracia Cristã da Catalunha (Minoria Catalã, 13); Partido Nacionalista Basco, PNV (8). Outros pequenos partidos somavam 9 representantes, formando o Grupo Misto.

9 Os seguintes partidos estiveram representados desde o início da Constituinte brasileira (o número de parlamentares está indicado entre parênteses): Partido do Movimento Democrático Brasileiro, PMDB (294); Partido da 
Frente Liberal, PFL (133); Partido Democrático Social, PDS (38); Partido Trabalhista Brasileiro, PTB (26); Partido Democrático Trabalhista, PDT (24); Partido dos Trabalhadores, PT (16); Partido Liberal, PL (8); Partido Socialista Brasileiro, PSB (6); Partido Comunista do Brasil, PCdoB (5); Partido Democrata Cristão, PDC (5); Partido Comunista Brasileiro, PCB (3); Partido Trabalhista Renovador, PTR (1).

10 Em sua inovadora análise dos jogos de linguagem nos processos constituintes, situada nas experiências americana de 1787 e francesa de 1789, Jon Elster (Argumenter et négocier dans deux Assemblées Constituantes. In: Revue Française de Science Politique, vol. 44, n. 2, 1994) destaca o uso de recursos extrapolíticos nas negociações constitucionais, considerando que os recursos políticos (ameaças, advertências e promessas) são pouco eficazes. Não se pode negar que a mobilização de recursos extrapolíticos também esteve presente nas Constituintes espanhola e brasileira, como exemplificam o papel cumprido pelas Forças Armadas, no primeiro caso, e pelo Poder Executivo, no segundo caso. Não obstante, a ausência de maioria absoluta favorecia a utilização de recursos políticos pelos atores, que se via reforçada, na Espanha, pela necessidade de aprovar a Constituição em referendo e, no Brasil, pelas incertezas das votações em plenário.

11 Essa opção metodológica não significa desconhecer que o processo de negociação de uma Constituição também se realiza em instâncias externas à Assembléia Constituinte, envolvendo diretamente os atores sociais, as quais, no entanto, não foram objeto de análise neste trabalho.

12 Esse recorte justifica-se pelo número reduzido de alterações trazidas aos projetos de Constituição pelas votações no Senado espanhol e no segundo turno da Constituinte brasileira.

13 A importância das fórmulas de compromisso nas Constituições democráticas foi destacada de modo pioneiro por Carl Schmitt. Cf. Teoría de la Constitución (Madrid: Alianza, 1982, p. 52-57). Ao contrário da visão de Schmitt, contudo, consideramos que as fórmulas de compromisso contêm normatividade, devendo ser diferenciadas das situações de nãodecisão, nas quais a Constituição não oferece pautas substantivas para a solução de conflitos.

14 As normas do regime autoritário que haviam servido de base para a convocação das duas Constituintes impunham que seu funcionamento seria bicameral na Espanha e unicameral no Brasil, e o quorum para aprovação final do texto, além da exigência de referendo no caso espanhol.

15 A Ponencia foi composta da seguinte maneira: UCD: 3 representantes, PSOE-PSC, PCE-PSUC, AP e Minoria Catalã: 1 representante cada.

16 Apesar da participação do Senado, o Congresso dos Deputados foi o principal fórum de debate e elaboração da Constituição. Além de sua maior representatividade, o Congresso era composto de um número maior de parlamentares, o que lhe daria vantagem em caso de divergências com o Senado, as quais seriam resolvidas por maioria absoluta em reunião conjunta das duas Casas.

17 I) Comissão da Soberania e dos Direitos e Garantias do Homem e da Mulher: A) Subcomissão da Nacionalidade, da Soberania e das Relações Internacionais; B) Subcomissão dos Direitos Políticos, dos Direitos Coletivos e Garantias; C) Subcomissão dos Direitos e Garantias Individuais.

II) Comissão da Organização do Estado: A) Subcomissão da União, Distrito Federal e Territórios; B) Subcomissão dos Estados; C) Subcomissão dos Municípios e Regiões.

III) Comissão da Organização dos Poderes e Sistema de Governo: A) Subcomissão do Poder Legislativo; B) Subcomissão do Poder Executivo; C) Subcomissão do Poder Judiciário e Ministério Público.

IV) Comissão da Organização Eleitoral, Partidária e Garantia das Instituições: A) Subcomissão do Sistema Eleitoral e Partidos Políticos; B) Subcomissão de Defesa do Estado; Sociedade e de sua Segurança; C) Subcomissão de Garantia da Constituição, Reformas e Emendas.

V) Comissão do Sistema Tributário, Orçamento e Finanças: A) Subcomissão de Tributos, Participação e Distribuição de Receitas; B) Subcomissão de Orçamento e Fiscalização Financeira; C) Subcomissão do Sistema Financeiro.

VI) Comissão da Ordem Econômica: A) Subcomissão de Princípios Gerais, Intervenção do Estado, Regime da Propriedade do Subsolo e da Atividade Econômica; B) Subcomissão da Questão Urbana e Transporte; C) Subcomissão da Política Agrícola e Fundiária e da Reforma Agrária.

VII) Comissão da Ordem Social: A) Subcomissão dos Direitos dos Trabalhadores e Servidores Públicos; B) Subcomissão de Saúde, Seguridade e Meio Ambiente; C) Subcomissão dos Negros, Populações Indígenas, Pessoas Deficientes e Minorias. 
VIII) Comissão da Família, da Educação, Cultura e Esportes, da Ciência e Tecnologia e da Comunicação: A) Subcomissão da Educação, Cultura e Esportes; B) Subcomissão da Ciência e Tecnologia e da Comunicação; C) Subcomissão da Família, do Menor e do Idoso.

18 O primeiro Projeto da Comissão de Sistematização foi duramente criticado, ao que se seguiu apresentação de dois substitutivos pelo Relator.

19 As 24 subcomissões temáticas funcionaram de 07.04 .1987 a 25.05 .1987 ; as 8 comissões temáticas, de 01.04,1987 a 12.06.1987; a Comissão de Sistematização, de 09.04.1987 a 18.11.1987; as votação de primeiro turno ocorreram de 03.02.1988 a 05.07.1988; e as votações de segundo turno, de 07.07.1988 a 02.09.1988.

$20 \mathrm{Na}$ Constituinte brasileira, uma emenda coletiva foi oferecida e aprovada como substitutivo para cada um dos oito títulos da Constituição, para o Preâmbulo e para o ADCT, o que fez dos destaques um mecanismo bastante utilizado, principalmente o destaque para aprovação, que visava preservar o texto da Comissão de Sistematização. Quanto à autoria, 44 dos 51 destaques aprovados no primeiro turno eram individuais, enquanto apenas 4 advieram da fusão de emendas e outros 3 destaques foram propostos através da co-autoria entre os parlamentares.

21 Isso também gerou o problema conhecido na Constituinte como "buraco negro". Derrubado o texto base por meio do DVS poderia ocorrer que nenhuma outra emenda obtivesse os 280 votos necessários para sua aprovação. Nesse caso, o Regimento previa que, em um prazo de 48 horas, o Relator ou a maioria dos parlamentares submeteriam ao Plenário uma fórmula conciliadora. O "buraco negro" ocorreu na votação de três matérias: (i) direito de propriedade; (ii) capítulo referente à política agrícola e à reforma agrária; (iii) direito de greve do servidor público.

22 Todas as emendas coletivas aos Títulos do Projeto de Constituição foram aprovadas, à exceção do Capítulo III da Ordem Econômica.

23 O cálculo do desvio padrão justifica-se pela grande variabilidade no número de votos recebidos pelas diferentes proposições nas Constituintes, evitando, ainda, a fixação de um percentual arbitrário para definir as votações consensuais e as votações não consensuais. Assim, utilizando como variável os votos "não" dados a cada proposição, calculou-se uma medida de 49 votos como grau máximo de dispersão no primeiro turno da constituinte brasileira e 15 votos para a votação da constituinte espanhola no Congresso dos Deputados. A partir da média aritmética (36 votos - Brasil, primeiro turno, e 04 votos - Espanha, Congresso dos Deputados), pode-se estabelecer o grau máximo de dispersão para enquadrar uma votação como consensual. Assim, numericamente, uma votação no primeiro turno da constituinte brasileira foi considerada consensual caso não ultrapassasse 85 votos "não", enquanto no processo espanhol o limite foi fixado em 19 votos "não". A escolha dos votos "não" como variável se justifica porque o "não" representa a contrariedade ao que se está votando, enquanto a base de votos "sim" pode ser influenciada pelo quorum, ou seja, o baixo número de "sim" em uma votação pode significar apenas que havia poucos parlamentares presentes naquele momento, não sendo suficiente para atestar se os ausentes da votação estavam contra ou a favor da matéria aprovada.

24 Sobre a Constituinte espanhola, v. Gregorio Peces-Barba Martinez, La elaboración de la Constitución de 1978 (Madrid: Centro de Estudios Constitucionales, 1988); J. F. Tezanos; R. Cotarelo; A. de Blas (Orgs), La transición democrática española (Madrid: Sistema, 1989); Francisco Rubio Llorente, El proceso constituyente en España. In: La forma del poder (Madrid: Centro de Estudios Constitucionales, 1997); José Maria García Escudero; Maria Asunción García Martínez, La Constitución día a día (Madrid: Congreso de los Diputados, 1998).

25 Tal fato foi destacado pelas lideranças dos partidos políticos já no primeiro dia de debates do projeto de Constituição. Para Herrero (UCD), o único caminho para chegar à democracia era a decisão soberana de uma assembléia constituinte: "Na realidade, nossa história é rica em experiência contrárias. Em 1876, a Constituição, com razão denominada canovista, foi um projeto governamental, ao que as Cortes se limitaram a dar um assentimento formal. Pelo contrário, em 1931 cedeu-se a uma tentação contrária e as Cortes ditaram uma Constituição que sucumbiu frente ao que caberia denominar sectarismo; quer dizer, frente à tentação de fazer uma Constituição válida para parte da Câmara, mas dificilmente aceita pela totalidade da representação nacional. Daí surgiram Constituições, em um e outro caso, qualificáveis de hemipléticas e muito úteis para serem utilizadas como armas pela metade da Espanha contra a outra metade, mas nas quais não se podia ver refletida a Espanha integral e total", (Constitución Española. Trabajos Parlamentarios, vol. I, Madrid, Cortes Generales, 1989, p. 637). A Constituição não deveria ser "a imposição de ninguém sobre ninguém, mas sim a imposição da vontade geral dos espanhóis, entendendo por vontade geral aquilo que há de geral e estatal em todo partido, aquilo que há de cidadão em todo homem concreto, aquilo que há de altruísta em toda reivindicação parcial e egoísta", (ibid., p. 637). 
Para Peces-Barba (PSOE): "Nós temos afirmado e defendido a necessidade do consenso. [...] devemos tender a não fazer um texto onde exista algo que seja absolutamente inaceitável para um Grupo Parlamentar. O consenso não é somente um problema quantitativo [...] entendemos que com esta Constituição todos devem poder governar; isto é, todos aqueles aos que a vontade popular leve ao Governo. [...] E pedimos desde esta perspectiva a todos os Grupos Parlamentares que tomem nota daqueles aspectos que supõem para nós graves dificuldades de aceitação, da mesma forma que nós estamos com a máxima atenção e com o máximo interesse escutando os argumentos dos demais Grupos Parlamentares para tomar boa nota, também, daquilo que possa ser absolutamente inaceitável para os demais", (ibid., p. 648-649).

O caráter principiológico da Constituição também ajudava o consenso. Segundo Carrillo (PCE): "Nós não vemos no projeto de Constituição nenhum obstáculo fundamental à realização de nossos ideais. [...] Certamente, desde uma óptica puramente partidária, essas objeções poderiam ser muito mais numerosas, intermináveis. [...] Mas trata-se de lograr uma Constituição capaz de conseguir o consenso da grande maioria. Uma Constituição que dure, que não seja facilmente empurrada por qualquer vendaval, como foram outras neste país. Ainda que não seja perfeita, que nos dê abrigo a todos e seja sólida", ibid., p. 651; 654-655).

Por fim, Fraga (AP) afirmou: "No passado, outra constante foi a imposição de uma fórmula constitucional por um grupo de espanhóis sobre os demais. Também pela primeira vez estamos trabalhando sobre pressupostos diferentes; o grupo constituinte é de amplo espectro, e cabe esperar que nossa obra, tanto na parte dos princípios dogmáticos quanto no desenvolvimento orgânico das instituições, permita diversas alternativas de programa político e de Governo e um turno pacífico entre as forças políticas e os blocos que o formem. [...] Ao estabelecer-se este pacto, quer dizer, ao renunciar a impor uns aos outros um 'trágala' constitucional, é evidente que o consenso só pode ser alcançado a partir de um clima de confiança. Um compromisso, entendido no sentido britânico, de um acordo baseado em mútuas concessões, só pode ser tal se as partes entram em um verdadeiro compromisso (no sentido espanhol, agora) com o pactado, não considerando-o como uma astúcia, como uma etapa em direção a outras metas. Isso exige também que as estipulações e as palavras do pacto constitucional signifiquem claramente o mesmo para todos, o que obriga a fugir de toda ambigüidade ou contradição nos termos. Finalmente, o compromisso não pode nunca chegar a cem por cento do escrito, e aí reside precisamente a verdadeira atitude de um consenso democrático, em aceitar, sem vetos nem reservas, essa parte inevitável de todo acordo parlamentar, que é o respeito à regra de maioria" (ibid., p. 655-657).

26 Nessa Câmara, o Rei poderia nomear um quinto de seus membros.

27 Cf. Gregorio Peces-Barba, La elaboración de la Constitución de 1978, p. 15-16.

28 Isso não significa que esse acordo tenha sido obtido sem tensões. Dentre os vários momentos difíceis vividos, ocorridos durante as negociações, pode-se destacar o abandono do representante socialista, Peces-Barba, dos trabalhos da Ponencia, alegando a recusa da UCD em aceitar as propostas do PSOE-PSC. Apesar disso, não era conveniente para a UCD compor a maioria com a AP, pois a exigência de submeter a Constituição a referendo colocava em risco a aprovação do projeto, caso não contasse com a adesão do eleitorado socialista. Da parte do PSOE-PSC, as declarações de seus membros indicam o reconhecimento da necessidade de fazer uma Constituição negociada com a UCD, disposição essa acentuada pela aposta de que o PSOE não tardaria a ganhar as eleições, preferindo uma Constituição de caráter principiológico, que não dificultasse seu possível governo. Assim, as lideranças dos dois maiores partidos encontraram-se várias vezes fora do Plenário ou no intervalo das sessões para negociar fórmulas que pudessem ser aceitas por ambas as partes.

29 Isso ocorreu nas votações sobre a forma de governo monárquica, direitos dos estrangeiros, menção à Igreja Católica, medidas de conflito coletivo, regras de sucessão da monarquia e Conselho de Estado, em que os socialistas se abstiveram, e nas votações sobre o direito à vida e o direito à sindicalização dos juízes, em que se posicionaram contra o texto aprovado.

30 Considerando o cálculo do desvio padrão, somente em duas situações o acordo UCD-PSOE-PSC gerou uma votação não consensual: o art. $2^{\circ}$, referente à definição de nação, e o art. 69 , referente à composição do Senado. Isso demonstra que o acordo entre os partidos majoritários teve êxito em incorporar as minorias, pois a mera soma de suas bancadas não seria suficiente para manter uma votação dentro do desvio padrão.

31 Ainda que o PSOE-PSC tenha mantido o voto republicano na Comissão Constitucional, fez questão de esclarecer que aceitaria o resultado da primeira votação sobre o tema. Nos debates da Comissão, seu representante Gomes Llorente assim se pronunciou: "Se, na atualidade, o Partido Socialista não se empenha como causa central e prioritária de seu fazer mudar a forma de Governo é, na medida em que pode abrigar razoáveis esperanças de que sejam compatíveis a Coroa e a democracia, de que a Monarquia se assente e se imbrique como peça de uma Constituição que seja susceptível de um uso alternativo pelos Governos de direita ou de esquerda que o povo determine através do voto e que viabilize a 
autonomia das nacionalidades e as regiões diferenciadas que integram o Estado. [...] Nós aceitaremos como válido o que resulte neste ponto do Parlamento constituinte. Não vamos questionar o conjunto da Constituição por isso. Acatamos democraticamente a lei da maioria. Se, democraticamente, estabelece-se a Monarquia, enquanto seja constitucional, nos consideraremos compatíveis com ela. O processo da reforma política torna inevitável que na sua ocasião o povo se pronuncie sobre o conjunto da Constituição, e posto que isso é previsível e racionalmente inevitável, não faremos obstrução, senão facilitaremos o máximo consenso a uma Constituição que deve fechar o quanto antes este período da transição e abrir o caminho a novas etapas de progresso e transformações econômicas e sociais, as quais em nada renunciamos, e para as quais só pretendemos ser um instrumento de nosso povo", (Constitución Española. Trabajos Parlamentarios, vol. I, Madrid, Cortes Generales, 1989, p. 773, 796-797). Vale destacar que o PNV também votou a favor da Monarquia, ainda que invocando seu compromisso histórico com a defesa dos direitos do povo basco.

32 Era a opinião de Fraga (AP): "Não prejulgo a atitude que meu Grupo possa tomar mais adiante e, desde já, esclareço que meu Grupo, examinando este tema diante de um eventual projeto de lei anunciado, reconheceu neste ponto, como questão de consciência, liberdade de voto a seus membros. Mas aqui não estamos discutindo essa lei, mas, de uma vez e para todos os casos, se introduz-se por via constitucional o tema da pena de morte, exclui-lo para todos os casos. [...] deixe-se essa questão para a lei; a lei pode matizar em um mesmo país umas circunstâncias e outras” (ibid., p. 990).

33 De acordo com Martín Toval (PSC), "abolir a pena de morte pela Constituição é absolutamente oportuno, porque seria um ato constituinte; portanto, um ato fundamental, um ato, se se prefere, de caráter filosófico, de crença humanística coletiva por cima da política dos partidos e dos interesses enfrentados”, (ibid., p. 991).

34 Ibid., p. 1006.

35 Ibid., p. 1008

36 Ibid., p. 1009.

37 O texto foi posteriormente modificado no Senado, sendo promulgada a seguinte redação: "Queda abolida la pena de muerte, salvo lo que puedan disponer las leyes penales militares para tiempos de guerra”, (art. 15).

38 Para o representante socialista Gómez Llorente: "Sem embargo, em plena consciência da responsabilidade que nos incumbe nesta Câmara e sabendo que o que votamos era o passo máximo, a atitude mais progressista que poderia terse na prática e com eficácia de modo a abolir a pena de morte, votamos como o fizemos. Não obstante, queremos fazer também aqui a afirmação de que seguiremos atuando na mesma linha de pensamento que nos inspirou sobre este ponto e que tentaremos, sem descanso, que na legislação ordinária fique definitiva e absolutamente abolida a pena de morte”, (Constitución Española. Trabajos Parlamentarios, vol. I, Madrid, Cortes Generales, 1989, p. vol. II, p. 2022, 2024).

39 Ibid., p. 2162.

40 Para Pons Irazazabal (PSOE): 'Entendemos que a fórmula do 'dictamen', cuja aprovação propomos, permite reconstruir um novo equilíbrio no qual estes dois fatores - tanto os poderes da Administração como as garantias dos administrados - saiam reforçados pelo bem da economia da sociedade, das próprias garantias dos cidadãos e, definitivamente, do país todo", (Constitución Española. Trabajos Parlamentarios, vol. II, p. 2164). Para Clar Garau (UCD), "Este artigo contém talvez uma das idéias básicas mais importantes do nosso ordenamento jurídico e que inclusive constituiu durante muitos anos a fronteira entre ideologias opostas. Por isso queremos demonstrar agora que o 31 vem a ser um artigo muito progressista e que rompe totalmente com a concepção tradicional que existia da propriedade privada", (ibid., p. 2166).

41 Ibid., vol. II, p. 2173.

42 Ibid., vol. II, p. 2174-2175.

43 A réplica ao pensamento de Fraga pode ser exemplificada pelo Deputado comunista Tamames Gomez: "[...] a Constituição deve ser um marco, um eixo de coordenadas dentro das quais possa mover-se o desenvolvimento econômico em razão da correlação de forças existentes. Tentar cristalizar a Constituição seria como ideologizá-la, e ideologizá-la seria como uma vitória de um determinado grupo sobre outro. [...] A mim me parece, insisto, que a redação atual é bastante correta, que se fala daquilo que há que se falar, de necessidades coletivas, de harmonizar o desenvolvimento regional, de 
buscar equilíbrios setoriais, também estimular o crescimento dos recursos do país. E que isso deve se fazer por meio de um plano, que será um plano de governo ou de uma coalizão governamental, que poderá ser em um momento dado indicativo somente para o setor privado ou vinculante para o setor privado em algumas proporções mais ou menos importantes, de acordo com o grau de intervenção do setor público em cada caso concreto”, (ibid., vol. II, p. 1447-1448).

44 Ibid., vol. II, p. 2330-2331.

45 Ibid., vol. II, p. 2344-2345.

46 De acordo com Silva Muñoz (AP), "se esgotamos até suas últimas conseqüências o argumento da neutralidade da Constituição, ao que chegaríamos, como conseqüência última inevitável, é a que a Constituição sobrava e que, por conseguinte, as leis ordinárias seriam as que teriam que resolver todos esses problemas”, (ibid., vol. I, p. 1141-1142).

47 Ibid., vol. I, p. 1142-1143.

48 Ibid., vol. II, p. 2113-2115.

49 Ibid., vol. I, p. 808-809.

50 Ibid., vol. I, p. 811.

51 Ibid., vol. I, p. 817-818.

52 Essa abertura é reconhecida pelos próprios parlamentares. Segundo Perez-Llorca Rodrigo (UCD): "Estamos prevendo para nosso país uma organização autônoma suficiente, flexível e aberta, com a intenção e o espírito de que se pacifiquem os problemas existentes nesse momento e que não se fechem as portas ao futuro, e que preservando a unidade nacional se possam ir solucionando gradualmente, a partir da Constituição, os velhos problemas históricos colocados em nosso país", (iibid., vol. II, p. 1537-1538). No mesmo sentido, afirma Solé Tura (PCE-PSUC): "Com isso quero dizer que este art. 141 não deve ser visto como artigo que fecha, mas como um artigo que abre; quer dizer, como um artigo que estabelece os limites máximos da competência do Estado central, mas ao mesmo tempo deixa aberta uma série de possibilidades de delegação para que essas faculdades sejam exercidas tanto a nível executivo quanto a nível regulamentar, como inclusive a nível legislativo em alguns casos, pelas Comunidades Autônomas", (ibid., vol. II, p. 1640).

53 Ibid., vol. I, p. 1162.

54 Apesar de seu caráter ainda mais polêmico, a votação sobre o direito à vida também pode exemplificar o acordo para não decidir. Houve consenso na troca da palavra "pessoa" por "todos" no seguinte dispositivo: "Todos tienen derecho a la vida y a la integridad física y moral, sin que, en ningún caso, puedan ser sometidos a tortura ni a penas o tratos inhumanos o degradantes" (art. 15). Apesar da resistência de AP, essa troca não implicava a legalização do aborto, tal como ficou demonstrado na igualmente polêmica sentença do Tribunal Constitucional sobre o tema, (ibid., vol. II, p. 2156).

55 Ibid., vol. I, p. 1012.

56 Ibid., vol. I, p. 1029.

57 Sobre a Constituinte brasileira, ver: Florestan Fernandes, $A$ Constituição Inacabada (São Paulo: Estação Liberdade, 1989); Bolívar Lamounier (Org.), De Geisel a Collor: o balanço da transição (São Paulo: Sumaré, 1990); Paulo Bonavides e Paes de Andrade, História Constitucional do Brasil (São Paulo: Paz e Terra, 1991).

58 Os Senadores eleitos em 1982, para um mandato de 8 anos, e que correspondiam a um terço da Casa, também integrariam a Constituinte. Apesar da semelhança de forma com o processo constituinte espanhol, a história constitucional brasileira já conhecia a atribuição de poderes constituintes ao Congresso Nacional, técnica que foi utilizada para a elaboração das Constituições de 1891, 1946 e 1967, sempre levando à limitação dos poderes da Assembléia.

59 A extensão dos poderes da Constituinte também foi objeto de grandes polêmicas, como exemplifica o "projeto de resolução", apresentado pelo Dep. Maurílio Ferreira Lima (PMDB), atribuindo à Constituinte o poder de editar "resoluções constitucionais" para alterar a Constituição então vigente, ou a proposta de suspensão do funcionamento do 
Congresso enquanto durasse a Constituinte. À direita, o Partido Liberal (PL) havia apresentado uma consulta ao STF sobre a vigência do processo de reforma constitucional, enquanto vários defendiam que o poder constituinte era reformador, e não originário.

60 Ao projeto de normas provisórias foram apresentadas 74 emendas, muitas delas buscando reforçar a soberania da Constituinte e limitar o papel dos líderes, (Anais da Assembléia Nacional Constituinte, Vol. 1, Brasília, Senado Federal, s/d, vol. 1, p. 35).

61 A manifestação do Deputado Amaral Netto (PDS) expressa as dificuldades da negociação: “Senhores, se não nos cedem nada, se não nos dão nada, agüentem com as conseqüências. Não estamos preocupados com a opinião pública neste momento. [...] não admitimos seis ou sete pontos terríveis neste Regimento. Pedimos que fossem modificados; não nos ouviram, ninguém conversou, ou, se conversou, apenas fingiu que o fez”, (ibid., p. 35, 595).

62 Ibid., vol. 1, p. 641.

63 Ibid., vol. 12, p. 6755.

64 Ibid., vol. 1, p. 641

65 Ibid., vol. 12, p. 6758.

66 Ibid., vol. 12, p. 6759.

67 Ibid., vol. 12, p. 6759.

68 Note-se que a votação do Título II, que incluía os direitos sociais, dificultava a obtenção de acordo, conforme anunciou Luiz Inácio Lula da Silva (PT): "O que percebo é que a tática adotada nas negociações aqui na Constituinte toma os mesmos rumos daquela entre sindicatos e trabalhadores e sindicatos patronais, quase sem qualquer objetivo. O 'Centrão', em suas críticas à Comissão de Sistematização, dizia que era preciso tripudiar sobre ela de toda forma, porque esta comissão estava tentando fazer um projeto socializante. Portanto, era preciso brecá-la, antes que aplicasse o socialismo neste País. O título II da Comissão de Sistematização foi colocado em xeque principalmente no que diz respeito aos interesses da classe trabalhadora brasileira: estabilidade no emprego, direito à greve, imprescritibilidade nos processos trabalhistas, direito do sindicato representar os trabalhadores e jornada de trabalho... Observamos, nas tentativas de negociação divulgadas pelos jornais, que os companheiros contrários ao texto da Comissão de Sistematização querem que aceitemos um acordo do qual não consta absolutamente nada de garantias efetivas para os trabalhadores", (ibid., vol. 12, p. 6756). Especificamente quanto aos direitos individuais, o PCdoB recusou-se a anuir ao substitutivo por estar nele incluído (i) o direito à propriedade, ao lado do elenco de outros direitos fundamentais no caput, art. $6^{\circ}$; (ii) a vinculação do crime de tortura ao de terrorismo; e (iii) a propriedade enquanto direito absoluto, com prévia e justa indenização em dinheiro para o caso de desapropriação. Haroldo Lima (PC do B) concluiu: "Então, Sr. Presidente, Srs. Constituintes, por estas três razões básicas, nós, do Partido Comunista do Brasil, ficamos fora do acordo. Não participamos deste entendimento que agora foi feito. Iremos, sim, votar contra o substitutivo do 'Centrão'" (ibid., vol. 12, p. 6758). Segundo Ademir Andrade (PSB): "Não aceitamos votar o caput do art. $6^{\circ}$, que iguala a questão da propriedade com o direito à vida. Não aceitamos votar que a propriedade não esteja submetida à subordinação do bem social. Não aceitamos votar que a desapropriação para efeito de utilidade pública ou para bemestar social seja paga em dinheiro, justa e prévia indenização em dinheiro, como está no projeto do 'Centrão'”, (ibid., vol. 12, p. 6758). Apesar das críticas, o número de votos contrários à emenda coletiva foi reduzido (56 votos), mantendo essa votação dentro do desvio padrão.

69 O entendimento é confirmado pela declaração do líder Mário Covas: “... votada esta proposta, todos nós estamos nos comprometendo a votar também o texto que, aliás, é comum na proposta da Comissão de Sistematização e na do 'Centrão', que prevê o pagamento em títulos da reforma agrária. Estamos nos comprometendo também a aprovar o texto que é comum, relativo à reforma urbana, ao do 'Centrão' e ao da Sistematização que, em determinadas circunstâncias, prevê o pagamento em títulos; e, mais que isto, estamos nos comprometendo também em comum, a aceitar o dispositivo do art. 191 que a condiciona à ordem econômica, à função social da propriedade e à preservação do meio ambiente", (ibid., vol. 12, p. 7201). Também o líder José Lourenço (PFL) confirma: “O entendimento político agora concluído, que atende aos interesses maiores do País, significa, para nós, que estão preservados os entendimentos anteriormente havidos, para pagamento em títulos da dívida agrária para a 
desapropriação de terras e pagamento em dinheiro para as benfeitoria. Para os imóveis urbanos ocorrerá o mesmo comportamento. Quanto à preservação do meio ambiente na defesa da ecologia, naturalmente todos nós e todos os partidos com assento nesta Casa têm a mesma visão do problema”, (ibid., vol. 12, p. 7201). Sem embargo, outros membros do Centrão negavam esse acordo, como, por exemplo, Bonifácio de Andrada: "O nobre Líder do PMDB referiu-se a compromissos em matéria posterior. O nosso compromisso do 'Centrão' é votar esse texto. Os conceitos de função social, de reforma agrária, de reforma urbana, como também de matéria ecológica, para nós são os que estão no projeto do “Centrão'”, (ibid., vol. 12, p. 7201).

70 Afirmou Mário Covas: "No momento, tendo em vista o fato de que V. Exa. irá colocar em votação o conjunto, quero dizer que, em relação à grande parte do texto global, houve acordos, embora parciais. Para que eles possam ser cumpridos, votaremos a favor, votaremos 'sim'. Mais do que isso, há certos textos sobre os quais não houve acordos, por isso o PMDB oportunamente se manifestará sobre eles com total liberdade para votar”, (ibid., vol. 13, p. 7520).

Segundo Gastone Righi (PTB): "Queremos, inicialmente, declarar que o PTB não foi consultado e, portant,o não apóia esse acordo que tem curso em Plenário. O PTB está contra ele e não concorda em transacionar, ainda mais pela forma insensata e irresponsável como foi feito. O dispositivo que este acordo pretende impor é absolutamente inaceitável. Aí não se garante ao trabalhador indenização ou estabilidade alguma ou emprego qualquer. Posterga-se isso tudo para uma legislação futura, que talvez os trabalhadores jamais vejam e, quiçá, seja a espada de Dâmocles a impedir ao empresariado seu desenvolvimento ou novos investimentos no País", (ibid., vol. 13, p. 7518).

Os partidos excluídos do acordo também manifestam fortemente sua discordância. Para Luiz Inácio Lula da Silva (PT): "É importante salientarmos que a chamada esquerda nesta Casa, da qual o Partido dos Trabalhadores faz parte, fez todo o possível para que conseguíssemos um acordo sobre a questão da estabilidade e dos direitos sociais. É verdade que, por diversas, sequer fomos ouvidos sobre o que pensávamos a respeito de questões importantes contidas nos direitos sociais. Achamos que o acordo feito é espúrio e não interessa ao conjunto da classe trabalhadora brasileira. [...] Muito nos surpreende o fato de os partidos considerados minoritários - o PT, o PDT, o PCdoB, os companheiros do PSB e porque não dizer os companheiros do MUP, como me falou aqui o companheiro Domingos Leonelli - terem sido deixados para escanteio pelas lideranças dos partidos majoritários, porque somos considerados radicais, sectários", (ibid., vol. 13, p. 7519).

71 Ibid., vol. 13, p. 7623.

72 Ibid., vol. 13, p. 7623.

73 Ibid., vol. 13, p. 7532.

74 Ibid., vol. 13, p. 7532.

75 Ibid., vol. 13, p. 7532.

76 Vale lembrar que esta lei ainda não foi editada.

77 "Depois de tentativas de acordo, produzimos algumas emendas relativas a determinados artigos sobre as quais, embora os textos do 'Centrão' e da Sistematização fossem diferentes, não havia grande divergência. Quanto aos pontos divergentes, o primeiro, como todos sabem, baseava-se na conceituação de empresa nacional e de empresa de capital nacional. Então, nos termos do acordo, ficou convencionado que votaríamos uma emenda de fusão com um texto completo e, a seguir, por não haver concordância sobre se a lei a vigorar no texto seria ou não complementar, votar-se-ia, subsidiariamente, se a lei seria complementar ou não. Há acordo em relação ao texto global e, com referência à lei complementar, cada partido votará segundo a sua vocação. No que diz respeito aos minérios, convencionou-se votar um texto básico que garante a nacionalização dos minérios estratégicos, definidos em lei, dos minerais contidos em faixa de fronteira e nas terras indígenas. Posteriormente, votar-se-á - isto no acordo -, a nacionalização total ou não. Finalmente, em termos de contrato de risco, manter-se-á o parágrafo da Sistematização, por acordo global, e votaremos posteriormente, nas Disposições Transitórias, um mecanismo que discipline os atuais contratos para que o País, as empresas e a Petrobrás não sejam prejudicados. É o texto do acordo feito, ressalvadas algumas outras emendas voltadas para os demais artigos, mas em relação aos quais não há grande discordância. Este acordo teve a participação de todos os partidos e, até onde eu sei, de todos os grupos existentes na Constituinte”, (ibid., vol. 17, p. 9892). Outras lideranças também se manifestaram pela aceitação do acordo geral. Gastone Righi (PTB): “Sr. Presidente, complementando a questão de ordem do ilustre líder Mário Covas, gostaria de declarar que a 
liderança do PTB votará a favor do substitutivo da emenda coletiva do 'Centrão', o que agora se coloca em votação. $\mathrm{O}$ acordo a que chegamos demonstra a postura correta, adotada ontem pela liderança do PTB, ao pleitear a abstenção, para que tivéssemos essas 24 horas, quando todas as lideranças chegaram ao consenso", (ibid., vol. 17, p. 9893). Amaral Netto (PDS): "Sr. Presidente, como Líder do PDS, não estive presente à reunião. Quero aqui ratificar o que ficou acordado com os Constituintes Jarbas Passarinho, Delfim Netto, Bonifácio de Andrada e Gerson Peres. Parabenizo os que conseguiram chegar a um acordo que não pode contentar a todos, mas satisfaz um pouco a cada um, e dá ao País a possibilidade de ter uma Constituição cuja votação não leve a litígios”, (ibid., vol. 17, p. 9893). Dep. Vladimir Palmeira (PT): "em primeiro lugar é preciso que fique claro que este é um texto de acordo. Portanto, é natural que nem todos estejam satisfeitos. Esta definição, portanto, por ser resultado de um acordo, não tem as qualidades que nós, da esquerda, gostaríamos que tivesse, mas ela evita o confronto, que nos poderia ser prejudicial, porque poderia ser aprovada a emenda do Centrão que diz: ‘Empresa brasileira é só aquela instalada no País'” (ibid., vol. 17, p. 9903). Ou ainda, as palavras do relator: “O ‘Centrão' fez concessões quanto ao controle decisório efetivo, à titularidade permanente e ao controle tecnológico. Isto é, quis fazer fusão”, (ibid., vol. 17, p. 9904).

78 A emenda aprovada continha o seguinte texto: "Art. 200. Será considerada empresa brasileira aquela constituída sob as leis brasileiras e que tenha no país sua sede e administração. $\S 1^{\mathrm{O}}$ - Empresa brasileira de capital nacional é aquela cujo controle efetivo esteja em caráter permanente sob a titularidade direta ou indireta de pessoas físicas domiciliadas e residentes no país ou de entidade de direito público interno. Entende-se por controle efetivo da empresa, para fins deste parágrafo, a titularidade da maioria de seu capital votante e o exercício, de fato e de direito, do poder decisório para gerir suas atividades. $\S 2^{\mathrm{O}}$ - A empresa brasileira de capital nacional poderá gozar, na forma da lei, de proteção e benefícios especiais temporários para desenvolver atividades consideradas estratégicas à defesa nacional ou imprescindíveis ao desenvolvimento tecnológico do país. $\S 3^{\mathrm{O}}$ - A lei prevista no parágrafo anterior, que considerar um setor imprescindível para o desenvolvimento tecnológico nacional, poderá ainda, com relação á empresa brasileira de capital nacional, entre outras condições e requisitos: a) Exigir que o controle referido no parágrafo primeiro se estenda às atividades tecnológicas da empresa, assim entendido o exercício de fato e de direito, do poder decisório para desenvolver ou absorver tecnologia, na forma por ela estabelecida; b) determinar percentuais de participação no capital das pessoas físicas domiciliadas e residentes no país ou entidade de direito público interno."

79 Ibid., vol. 17, p. 9912.

80 O texto do caput fora aprovado, sem nenhum encaminhamento contra e resultante de fusão, com o seguinte teor: "Art. 205. As jazidas, minas e demais recursos minerais e os potenciais de energia hidráulica constituem propriedade distinta do solo para efeito de exploração ou aproveitamento industrial e pertencem à União, garantida ao concessionário ou autorizado a propriedade do produto da lavra. Parágrafo único. É assegurada ao proprietário do solo a participação nos resultados da lavra; a lei regulará a forma e o valor da participação".

80 Cf. Eliseo Aja. El Estado Autonómico (Madrid: Alianza, 1999) e Antonio G. Moreira Maués; Itziar Gómez Fernández (Orgs.) Ordenamiento Territorial en Brasil y España (Valencia: Tirant lo blanch, 2005).

\section{REFERÊNCIAS BIBLIOGRÁFICAS}

AJA, Eliseo. El Estado Autonómico. Madrid: Alianza, 1999.

ANAIS da Assembléia Nacional Constituinte, Vol. 1. Brasília: Senado Federal, [s.d.].

BONAVIDES, Paulo; ANDRADE, Paes de. História Constitucional do Brasil. São Paulo: Paz e Terra, 1991.

CONSTITUCIÓN Española. Trabajos Parlamentarios, vol. I. e II. Madrid: Cortes Generales, 1989.

COUTINHO, Jacinto Nelson de Miranda (Org.). Canotilho e a Constituição Dirigente. Rio de Janeiro: Renovar, 2003.

DAHL, Robert. La Poliarquia. Participación y oposición. Madrid: Tecnos, 1989

ESCUDERO, José Maria García; MARTíNEZ, Maria Asunción García. La Constitución día a día. Madrid: Congreso de los Diputados, 1998.

ELSTER, Jon. Argumenter et négocier dans deux Assemblées Constituantes. In: Revue Française de Science Politique, vol. 44, n. 2, 1994.

FERNANDES, Florestan. A Constituição Inacabada. São Paulo: Estação Liberdade, 1989. 
HESSE, Konrad. Escritos de Derecho Constitucional. Madrid: Centro de Estudios Constitucionales, 1992.

HOLMES, Stephen. Precommitment and the paradox of democracy. In: ELSTER, Jon; SLAGSTAD, Rune (Eds.). Constitutionalism and Democracy. Cambridge: Cambridge University Press, 1988.

LAMOUNIER, Bolívar (Org.). De Geisel a Collor: o balanço da transição. São Paulo: Sumaré, 1990.

LLORENTE, Francisco Rubio. El proceso constituyente en España. In: La forma del poder. Madrid: Centro de Estudios Constitucionales, 1997.

MARTINEZ, Gregorio Peces-Barba. La elaboración de la Constitución de 1978. Madrid: Centro de Estudios Constitucionales, 1988 .

MAUÉS, Antonio Gomes Moreira. Poder e Democracia: O Pluralismo Político na Constituição de 1988. Porto Alegre: Síntese, 1999

; Itziar Gómez Fernández (Orgs.) Ordenamiento Territorial en Brasil y España. Valencia: Tirant lo blanch, 2005. PECES-BARBA, Gregório. La elaboración de la Constitución de 1978. [s.n.t.].

SCHMITT, Carl. Teoría de la Constitución. Madrid: Alianza, 1982.

TEZANOS, J. F.; COTARElO, R.; BLAS, A. de (Orgs.). La transición democrática española. Madrid: Sistema, 1989.

Av. Serzedelo Corrêa, 1035/202

Batista Campos - 66033-770

Belém - PA - Brasil

amauesdamazon.com.br

Rua Almirante Gago Coutinho, n 43

$4^{\circ}$ esquerdo $-3030-326$

Coimbra - Portugal

elidalauris@gmail.com
Antonio Gomes Moreira Maués

Professor Associado da Universidade Federal do Pará PESquisador dO CNPQ

\section{Élida Lauris dos Santos}

Mestre em Direito pela Universidade Federal do Pará Doutoranda EM Sociologia PELA Universidade dE CoImbra 